\title{
Sialylated Oligosaccharides and Glycoconjugates of Human Milk. The Impact on Infant and Newborn Protection, Development and Well-Being
}

\author{
Jolanta Lis-Kuberka and Magdalena Orczyk-Pawiłowicz * $\mathbb{D}$ \\ Department of Chemistry and Immunochemistry, Wrocław Medical University, Bujwida 44a, \\ 50-345 Wrocław, Poland; jolanta.lis-kuberka@umed.wroc.pl \\ * Correspondence: magdalena.orczyk-pawilowicz@umed.wroc.pl; Tel.: +48-71-328-26-95
}

Received: 2 January 2019; Accepted: 29 January 2019; Published: 1 February 2019

\begin{abstract}
Human milk not only has nutritional value, but also provides a wide range of biologically active molecules, which are adapted to meet the needs of newborns and infants. Mother's milk is a source of sialylated oligosaccharides and glycans that are attached to proteins and lipids, whose concentrations and composition are unique. Sialylated human milk glycoconjugates and oligosaccharides enrich the newborn immature immune system and are crucial for their proper development and well-being. Some of the milk sialylated oligosaccharide structures can locally exert biologically active effects in the newborn's and infant's gut. Sialylated molecules of human milk can be recognized and bound by sialic acid-dependent pathogens and inhibit their adhesion to the epithelial cells of newborns and infants. A small amount of intact sialylated oligosaccharides can be absorbed from the intestine and remain in the newborn's circulation in concentrations high enough to modulate the immunological system at the cellular level and facilitate proper brain development during infancy. Conclusion: The review summarizes the current state of knowledge on sialylated human milk oligosaccharides and glycoconjugates, discusses the significance of sialylated structures of human milk in newborn protection and development, and presents the advantages of human milk over infant formula.
\end{abstract}

Keywords: human milk; nutrition; sialic acid; free oligosaccharides; glycoproteins

\section{Introduction}

Human milk is a highly complex fluid, which is produced locally by mammary epithelial cells, but also contains molecules that are filtered from the mother's plasma. The biochemical analysis of human milk showed that the concentrations of individual components of mother's milk are dependent on the gestational age [1,2], milk maturation stages [2-5], the health status of the mother [6,7], and perinatal risk factors [2]. Moreover, the composition of mother's milk is related to the phase of the day [8], as well as the change during feeding (foremilk and hindmilk) [9]. Human milk, apart from nutrient balance, has an array of functional properties, namely anti-pathogenic, anti-infective, anti-inflammatory, and immunomodulatory. An important component of human milk is sialylated and fucosylated molecules, which constitute an essential element of innate immunity passed to the newborn with the mother's milk. Currently, the WHO (World Health Organization) and ESPGHAN (European Society for Paediatric Gastroenterology Hepatology and Nutrition) guidelines on nutrition care for newborns and infants indicate that human milk is not only the best nutrient for the baby during the first six months of life but is also used as a medicine at neonatal intensive care units (NICUs) [10-12]. 


\section{Biological Role of Sialic Acid}

$\mathrm{N}$-acetylneuraminic acid (Neu5Ac), commonly known as sialic acid, is one of the more than 40 monosaccharides, and belongs to the family of derivatives of neuraminic acid (5-amino-3,5-dideoxy-D-glycero-D-galacto-non-2-ulosonic acid). Sialic acid is an acidic monosaccharide built up of nine carbon atoms, which, at anomeric carbon $\mathrm{C} 2$, has a free carboxyl group and at C5 an N-acetyl group (Figure 1) [13-15]. Sialic acid and fucose present in the structure at the terminal position of oligosaccharide chains according to the hypothesis of Gabius and coworkers [16] encode a significant amount of information, which is important in the regulation of signal transduction among cells and between cells and biomolecules. Such events are highly dependent on the composition, conformation, and sequence of monosaccharides, which form oligosaccharide chains / and glycotopes $[13,15,17]$. Moreover, the presence of sialic acid in oligosaccharide chains of glycoproteins protect them against the removal from the circulation by specific asialoglycoprotein receptors of hepatic and Kupffer cells as well as by peritoneal macrophages [18].

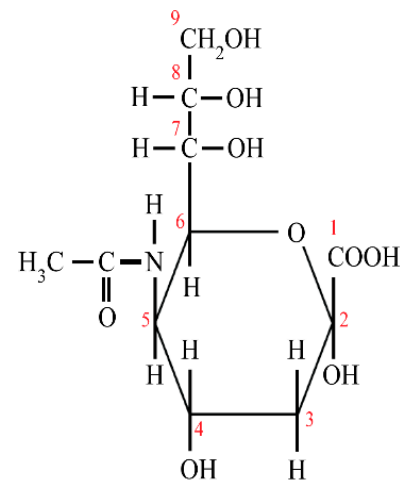

Figure 1. The structure of sialic acid. 1-9-the number of carbon atoms

Sialic acid may be linked by $\alpha 2,3$ - and $\alpha 2,6$-glycosidic bonds, but the biological role of $\alpha 2,3-$ and $\alpha 2,6-$ linked sialic acids has been suggested to be quite different. Glycotopes containing $\alpha 2,3$-sialic acid, being a part of sialyl-Lewis $\mathrm{x}$ (sLeX) glycotopes, are classified as "carcino-embryonic" type, while containing $\alpha 2,6$-sialic acid as a "mature" type [13,15]. It was reported that the increase of $\alpha 2,3$ - and/or $\alpha 2,6$-sialylated glycotopes on $\mathrm{N}$ - and/or O-glycans is associated with inflammation, cancerogenesis, and metastasis $[19,20]$. In addition, sialic acid might also form polysialic acid structures in which Neu5Ac molecules are connected to each other by $\alpha 2,8$ linkage [21,22]. Polysialic acid structures are critical for nervous system development and maintenance, and also for cancer metastasis, tissue regeneration, and repair and neuroinvasive potential of pathogenic bacterial strains [21].

Glycotopes containing sialic acid serve as a recognition determinant and can modulate many cellular mechanisms, proliferation of cells and differentiation of tissues [23,24], signal transduction [17], interactions between cells, cells and extracellular matrix, as well as cells and soluble ligands, thereby participating in biological recognition processes $[14,15,17,25]$. The participation of sialylated glycotopes in physiopathological processes, such as embryogenesis [26], fertilization [27], fetal development [24], selectin-mediated leukocyte adhesion to endothelium [28], apoptosis [29], inflammation [30], and cancer and immune diseases [15] has been confirmed. In addition, sialic acid plays an important role in the interactions between the host cells and pathogens, being a ligand for the lectin receptor of some sialic acid-dependent pathogens [15].

\section{Sialylated Structures of Human Milk}

Human milk is a rich source of sialylated structures such as human milk oligosaccharides (HMOs), glycoconjugates such as glycoproteins and glycolipids, and also contains sialic acid as a free molecule. The total sialic acid concentration in human term milk is the highest at the beginning of lactation and reaches $5.04 \pm 0.21 \mathrm{mmol} / \mathrm{L}$ at days one-six, then decreases to the values of $1.98 \pm 0.08 \mathrm{mmol} / \mathrm{L}$ and 
$1.04 \pm 0.06 \mathrm{mmol} / \mathrm{L}$ at one and three months of lactation, respectively [17]. The most abundant sialylated human milk molecules are human milk oligosaccharides. About 70-83\% of all sialic acid present in human milk is bound with HMOs, $14-28 \%$ with glycoprotein glycans and $0.2-0.4 \%$ with glycolipids (primarily gangliosides) [31,32]. The concentration and distribution of sialylated human milk glycoconjugates depend on milk maturation stages and the length of pregnancy [2,32,33]. The milk of mothers who delivered preterm contained about $13-23 \%$ more sialic acid compared to the term milk at the first and third months of lactation [32].

\subsection{Sialic Acid in Human Milk Oligosaccharides}

Thus far, more than 200 different structures of HMOs, built from 3-22 monosaccharides, have been identified [34-38]. However, based on the recent review by Urashima and coworkers, according to the Consortium for Functional Glycomics (CFG) of USA, 247 varieties of HMOs have been separated, of which 162 chemical structures have been characterized [39].

The synthesis of HMOs takes place in the Golgi apparatus of maternal mammary alveolar cells [40]. For the majority of HMOs, the first step, namely the lactose core formation, is catalyzed by $\beta 4$-galactosyltransferase one in the presence of $\alpha$-lactalbumin [41]. In further steps, lactose can be elongated enzymatically by addition of monosaccharides such as N-acetylglucosamine (GlcNAc), galactose (Gal), fucose (Fuc), and sialic acid (Neu5Ac). The fucose can be attached by glycosidic linkage $\alpha 1,2$ to the galactose (Gal) and/or $\alpha 1,3 / 4$ to the GlcNAc, while sialic acid residues can be attached by $\alpha 2,3$ and/or $\alpha 2,6$ linkages to the terminal or subterminal galactose and/or N-acetylglucosamine (Figure 2) and cannot be substituted by other monosaccharides $[41,42]$. In a rodent model, $\beta$-galactoside sialyltransferases, namely ST3Gal4 and ST6Gal1 are involved in the biosynthesis of 3'- and 6'-sialyllactose, respectively [6], but data to prove their involvement in sialylated HMOs biosynthesis are missing [34]. Based on the presence of sialic acid, HMOs are divided into acidic oligosaccharides (with one or more sialic acid molecules) and neutral oligosaccharides without sialic acid molecules.

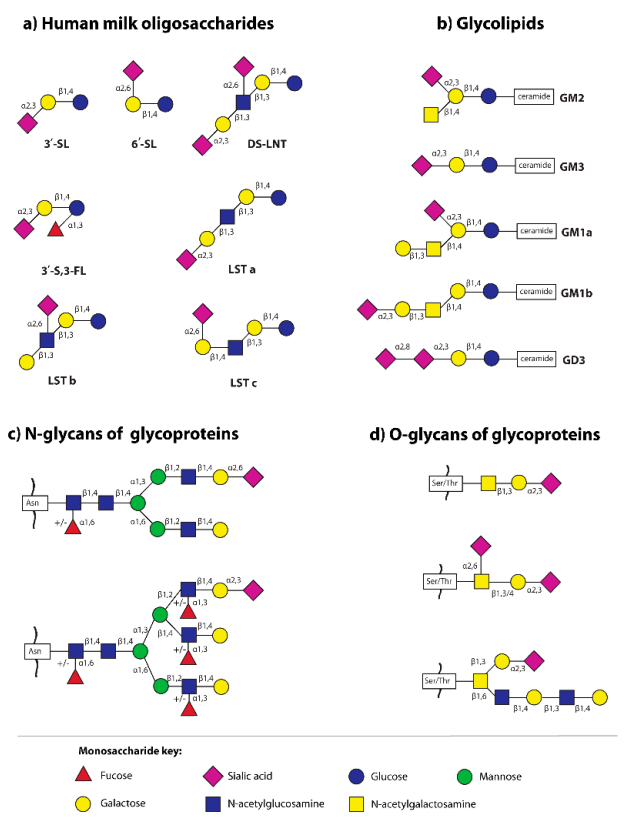

Figure 2. The main sialylated structures of human milk oligosaccharides and glycoconjugates (glycoproteins and glycolipids) $[35,41,43,44]$. (a) Human milk oligosaccharides: $3^{\prime}$-SL-3'-sialyllactose; 3'-S,3-FL-3'-sialyl-3-fucosyllactose; $\quad 6^{\prime}$-SL-6'-sialyllactose; DS-LNT—disialyllacto-N-tetraose; LST—sialyllacto-N-tetraose; (b) Glycolipids: GM-monosialoganglioside, GD—disialoganglioside; (c) Sialylated N-glycans of glycoproteins-the two most common structures in human milk N-glycome are presented [43]; Asn-asparagine; and (d) Sialylated O-glycans of human milk S-IgA [44]; Ser-serine, Thr-threonine. 
Due to structural complexity of HMOs, as well as lack of standards and different methods used by different laboratories for determinations of HMOs concentration, and as inter-individual differences among healthy lactating mothers, the available data can differ. The concentration of HMOs varies during milk maturation. The highest concentration is in colostrum $20 \mathrm{~g} / \mathrm{L}$ and then substantially decreases to $16 \mathrm{~g} / \mathrm{L}$ at day 30 of lactation [45]. The latest research by $\mathrm{Xu}$ and coworkers [46] showed that the concentration of HMOs at the 10th day of lactation was $19.3 \pm 2.9 \mathrm{~g} / \mathrm{L}$ and then decreased to the value $8.53 \pm 1.18$ at the 120th day of lactation. Moreover, the concentration of HMOs can vary depending on the week of delivery [47,48]. According to Morrow and coworkers [48], the concentration of total HMOs in preterm milk from days 10-23 of lactation was nearly two-fold lower than in term milk in the same period of lactation $(3.6 \mathrm{~g} / \mathrm{L}$ and $6.1 \mathrm{~g} / \mathrm{L}$, respectively). On the other hand, the latest research by Kunz and coworkers [49] showed that the total HMOs concentration in preterm milk did not differ significantly from term milk, either for colostrum (preterm: $8.7 \mathrm{~g} / \mathrm{L}$ and term $7.5 \mathrm{~g} / \mathrm{L}$ ) or for transitional milk (preterm: $8.6 \mathrm{~g} / \mathrm{L}$ and term: $9.1 \mathrm{~g} / \mathrm{L}$ ) or for mature milk (preterm: $8.6 \mathrm{~g} / \mathrm{L}$ and term: $8.2 \mathrm{~g} / \mathrm{L}$ ). However, different mothers synthesize different subsets of milk oligosaccharides. The most extreme inter-individual variations are related to HMOs fucosylation and are based on mother's secretor and Lewis blood group status. The majority of mothers express the $\alpha 2$-fucosyltransferase (FUT2), which is responsible for the addition of fucose via $\alpha 1,2$ linkage to terminal Gal [50] to form 2-fucosylated structures in milk (2'-fucosyllactose and LNFP-I are some of the most abundant) of so-called "secretor" mothers [51-53] in contrast to "non-secretor" mothers who do not express FUT2. The total HMOs concentration is "secretor" status-dependent [49,52]. In milk from "secretor" mothers, the total HMOs concentration was significantly higher compared with milk from "non-secretor" mother's colostrum (median, $9.67 \mathrm{~g} / \mathrm{L}$ vs $5.17 \mathrm{~g} / \mathrm{L}$ ), transitional (median, $9.47 \mathrm{~g} / \mathrm{L}$ vs $5.61 \mathrm{~g} / \mathrm{L}$ ), and mature milk (median, $8.67 \mathrm{~g} / \mathrm{L}$ vs $5.54 \mathrm{~g} / \mathrm{L})[49]$.

The data concerning contribution of fucosylated, sialylated, and nonfucosylated neutral HMOs fractions are not unequivocal. According to Ninonuevo and coworkers [54,55], the proportions of fucosylated and sialylated HMOs in human term milk are $60-80 \%$ and $10-15 \%$, respectively [54], and do not vary significantly at different stages of lactation [55]. On the other hand, as reviewed by Donnovan and Comstock [56], the content of fucosylated, sialylated, and nonfucosylated neutral HMOs in term milk is different, namely $~ 35-50 \%, 12-14 \%$, and $42-55 \%$. Moreover, as reported by Thurl and coworkers [52] and by Kunz and coworkers [49] milk samples of "secretor" and "non-secretor" mothers exhibited significant qualitative and quantitative differences in human milk oligosaccharides during the first three months of lactation.

In contrast to fucosylated HMOs, the concentration of sialylated HMOs do not exhibit important differences among "secretor" mothers with Lewis blood group Le $(a-b+) 2.23 \mathrm{~g} / 1$, "secretor" mothers with blood type Le(a-b-) 2.48, and for "non-secretor" mothers with Lewis blood group Le(a+b-) $2.17 \mathrm{~g} / 1$ [49,52]. However, all milk groups exhibited an almost parallel decrease to one-third of the initial acidic oligosaccharides concentrations during the first three months of lactation [52]. Additionally, the concentration of sialylated HMOs in milk from secretor-mothers of healthy infants was significantly higher than in the milk of mothers of stunted infants [57].

The simplest sialylated oligosaccharides present in milk are trisaccharides, such as $3^{\prime}$-sialyllactose ( $\left.3^{\prime}-\mathrm{SL}\right)$ and $6^{\prime}$-sialyllactose ( $6^{\prime}$-SL), which are formed by the addition of sialic acid by $\alpha 2,3-$ and $\alpha 2,6$-glycosidic bonds to the galactose of lactose, respectively (Figure 2) $[7,20,41,58,59]$. The other oligosaccharides occurring in human milk containing $\alpha 2,3-$ and/or $\alpha 2,6-$ linked sialic acid are disialyllacto-N-tetraose (DS-LNT), and present in lower concentrations, sialyllacto-N-tetraoses (LSTa, LSTb, and LSTc) (Figure 2) [58].

Based on a summary published by Thurl and coworkers [58], the mean concentration of 3'-SL, $6^{\prime}$-SL and DS-LNT in term milk from secretor mothers during the first 100 days of lactation was 0.19 , 0.64 and $0.50 \mathrm{~g} / \mathrm{L}$, respectively. Comparable data were reported by Donnovan and Comstock [56], namely for 3'-SL $0.2(0.1-0.3) \mathrm{g} / \mathrm{L}$ and for $6^{\prime}$-SL $0.5(0.2-1.22) \mathrm{g} / \mathrm{L}$ and by Sprenger and coworkers [60] at one month of lactation for $3^{\prime}-\mathrm{SL} 0.22 \mathrm{~g} / \mathrm{L}$ and for $6^{\prime}-\mathrm{SL} 0.5 \mathrm{~g} / \mathrm{L}$. Similar concentrations of $3^{\prime}-\mathrm{SL}$ and 
$6^{\prime}$-SL in preterm milk $(0.24$ and $0.60 \mathrm{~g} / \mathrm{L})$ during the first 30 days of lactation were observed [58]. Moreover, the concentrations of sialylated HMOs, namely 6'-SL, 3'-SL, and DS-LNT, as suggested by McGuire and coworkers [61], vary geographically. However, the authors pointed out that to confirm such as hypothesis targeted genomic analyses are required to determine whether these differences are due at least in part to genetic variation. The level of all sialylated HMOs was more than two times higher in the milk of mothers in Ghana (mean $3.6 \mathrm{mmol} / \mathrm{L}$ ) than in milk of mothers in Sweden (mean $1.6 \mathrm{mmol} / \mathrm{L}$ ). However, for two sialylated structures of HMOs, namely for 6'-SL and DS-LNT, the concentrations were more than four and 2.5 times higher, respectively, in milk of mothers in Ghana than in the milk of Swedish mothers [61].

\subsection{Sialic Acid in Human Milk Glycoproteins}

Sialic acid can be linked by $\alpha 2,3$ - and/or $\alpha 2,6$-glycosidic linkages to the terminal galactose (Gal) of N-glycans and by $\alpha 2,3-$ and/or $\alpha 2,6$-glycosidic linkages to the terminal galactose (Gal) and/or subterminal N-acetylgalactosamine (GalNAc) of O-glycans of glycoproteins (Figure 2) $[41,43,44]$. Nevertheless, the sialic acid can be substituted by other sialic acids linked by $\alpha 2,8$-glycosidic bonds to make polysialic acid, e.g., CD36 protein of the human milk fat globule outer membrane is decorated by O-glycans with polysialic acid [21,22].

$57 \%$ of N-glycans of human milk glycoproteins are sialylated [43]. Additionally, the analysis of the sialylation profiles of secretory immunoglobulin A (S-IgA) and lactoferrin (LF) in milk of mothers with gestational diabetes mellitus showed a lower for S-IgA and higher for LF content of sialylated $\mathrm{N}$-glycans compared to the milk of healthy mothers [7].

Detailed studies have shown that, during milk maturation, the sialylation pattern of human skim milk glycoprotein differs in relation to the type of sialic acid linkage to the glycan part of glycoprotein, as well as to the analyzed glycoprotein $[4,5,33]$. The overall relative amounts of $\alpha 2,6-$ and $\alpha 2,3$-sialylated glycotopes of human milk glycoproteins at days $39-47$ of lactation were $33 \%$ and $89 \%$ of those observed for colostrum, respectively [33]. However, for some glycoproteins no significant differences were observed during lactation. The overall changes observed for $\alpha 2,6-$ and $\alpha 2,3$-sialylation patterns of human skim milk glycoproteins correspond to term milk maturation and overlap with trends for sialylated HMOs, namely, $6^{\prime}$-SL, 3'-SL, and DS-LNT [58] over lactation.

It is also worth paying attention to the fact that some glycoproteins, which were detected in human milk, are also found in plasma, although their glycosylation profile is quite different. The alternations in glycosylation patterns are related to some locally synthesized glycoproteins, namely immunoglobulin G (IgG) [2], $\alpha_{1}$-acid glycoprotein (AGP) [4], and fibronectin (FN) [5] by alveolar cells of the mammary gland, which is hormonally regulated [34,62].

\subsection{Sialic Acid in Human Milk Glycolipids}

In milk, glycolipids are found almost exclusively as a component of the outer layer of the milk fat globule membrane [9,63-66]. Glycolipids of human milk are divided into neutral glycolipids (glycolipids without sialic acid) such as glucosylceramide, galactosylceramide, and acidic glycolipids, with sialic acid in their structures, namely gangliosides, which are the most abundant fraction of human milk glycolipids [64-67].

The data concerning the total concentration of lipid-bound sialic acid (T-LBSA) during milk maturation are inconsistent. As reported by Pan and Izumi [67], the concentration of T-LBSA is not dependent on milk maturation stages, reaching $9.5 \pm 1.2 \mathrm{mg}$ T-LBSA/L in colostrum and $9.1 \pm 1.2 \mathrm{mg}$ T-LBSA/L in mature milk. On the other hand, Giuffrida and coworkers [68], using liquid chromatography coupled with electrospray ionization high resolution mass spectrometer (LC/ESI-HR-MS), reported a slight increase in total gangliosides from $8.1 \mathrm{mg} / \mathrm{L}$ during the first 11 days of lactation to the value of $10.7 \mathrm{mg} / \mathrm{L}$ at the 4 th month of lactation. Moreover, differences in the content of particular fractions of gangliosides are also observed. The main gangliosides of human milk are monosialoganglioside 3 (GM3, Neu5Ac $\alpha 2,3 \mathrm{Gal} \beta 1,4 \mathrm{Gl} c \beta 1,1$ ceramide) and disialoganglioside 3 (GD3, 
Neu5Ac $\alpha 2,8$ Neu5Ac $\alpha 2,3$ Gal $\beta 1,4$ Glc $\beta 1,1$ ceramide), while GM2 and GM1 represent a small fraction ( $2 \%$ and $0.1 \%$, respectively) (Figure 2) $[41,65,69,70]$. It was reported that the concentration of human milk GM3 increases, while the concentration of GD3 decreases during lactation [69]. According to Giuffrida and coworkers [68], the concentrations of GD3 and GM3 in human milk at the beginning of lactation, between postpartum days zero and 11 , were at a similar level ( 3.8 and $4.3 \mathrm{mg} / \mathrm{L}$, respectively), while at day 30, the concentrations were 1.7 and $7.4 \mathrm{mg} / \mathrm{L}$, respectively. On subsequent days of lactation the differences between concentrations of GD3 and GM3 were even greater, 0.9 and $9.1 \mathrm{mg} / \mathrm{L}$, respectively, and then at day 120, remained at a stable level (0.9 and $9.8 \mathrm{mg} / \mathrm{L}$, respectively) [68].

\section{Metabolism of Sialic Acid by Infants}

Karim and Wang [71], based on analysis of the enzymes involved in the synthesis of sialic acid in a rodent model, suggest that liver and other organs of newborns may not have the full ability to synthesize sialic acid during the first two weeks of their postnatal life. In light of the above, a very important part of the diet of newborns and infants is sialic acid delivered with mother's milk. The high level of sialic acid in mother's milk at the beginning of lactation is an evolutionary adaptation, to compensate for the partial capacity of the newborn and infant's liver to synthesize endogenous sialic acid [71]. However, it should be pointed out that there are only speculations based on data from animal studies, which do not reflect the glycosylation pathways utilized by humans.

As sialic acid is delivered with mother's milk, mainly in bound form (HMOs, glycoproteins and glycolipids), its metabolism in the body of newborns and infants involves a series of reactions to release this monosaccharide from glycoconjugates. In a rat model, high activity of neuraminidase in the intestinal mucosa is probably related to a high level of sialylated molecules in the milk [71]. The administration of guinea pigs with radiolabeled sialyllactose resulted in its $\sim 90 \%$ absorption from the intestine within four hours, and then it was used as a substrate for the synthesis of new sialylated glycoconjugates of tissues $(30 \%)$ and brain $(\sim 3 \%)$ [72]. On the other hand, intravenous administration of three-day old piglets with labeled free sialic acid showed that, within two hours, $0.23 \%$ was located in the brain $[59,73]$.

In the plasma of partially breastfed infants the pattern of sialylated HMOs such as $3^{\prime}$-SL $(\sim 23 \%), 6^{\prime}$-SL $(\sim 3 \%), 3^{\prime}-$ SLN $(\sim 14 \%)$, and $6^{\prime}$-SLN $(\sim 23 \%)$ was quantitatively different from exclusively formula-fed infants: $3^{\prime}$-SL $(\sim 51 \%), 6^{\prime}$-SL $(\sim 1 \%), 3^{\prime}$-SLN $(\sim 8 \%)$, and $6^{\prime}$-SLN $(\sim 10 \%)$, respectively [74]. These findings support the hypothesis that HMOs-related sialic acids are transported to the lumen of the small intestine or colon of newborns and infants and are then absorbed into their plasma [74]. Moreover, HMOs present in the bloodstream of infants are excreted with the urine. Additionally, a significantly higher level of $6^{\prime}-\mathrm{SL}(26.1 \pm 17.2 \mathrm{mg} / \mathrm{L})$ in urine of breastfed infants in comparison to formula-fed infants $(0.9 \pm 0.3 \mathrm{mg} / \mathrm{L})$ was observed [75].

Surprisingly, in the urine and feces of both breast and formula-fed infants, the presence of $6^{\prime}$-sialyllactosamine (6'-SLN), which was not found in mother's milk and plasma, was detected $[75,76]$. Simultaneously, Ruhaak and coworkers [74] confirmed the presence of 6'-SLN and a new, unknown isomer of SLN in infant plasma. The 'modified' HMOs in the newborn's urine may be synthesized endogenously from smaller precursors [77]. Additionally, the "new" HMOs may be the result of bacterial fermentation of milk glycoconjugates or a part of glycan structures present on cell surfaces [78].

The metabolism and functions of HMOs are intensively studied based on an animal model. Jantscher-Krenn and coworkers [79] reported that, in a rat model, only 3'-sialyllactose and hardly any other HMOs appeared in the serum and the urine of HMOs-fed rats and suggested a selective absorption of rat milk-specific oligosaccharides. However, subsequent studies have shown that an oral administration of an individual $\mathrm{HMO}$, such as $2^{\prime}-\mathrm{FL}, 6^{\prime}-\mathrm{SL}$, and LNnT, which were partially absorbed into the plasma and excreted in urine impacted the concentration of other HMOs in serum and in urine of pups and adult rats. Additionally, such an effect was more evident when the higher doses of oligosaccharides were administered. Moreover, the observed changes were more detectable in urine than in serum. However, further studies are needed to understand this phenomenon [80]. 


\section{Metabolism of Sialic Acid by Infants Microbiota}

Microorganisms, which form the intestinal flora of newborns and infants, namely the microbiota, participate in the metabolism of human milk glycoconjugates [81]. Microbiota composition depends on the feeding type $[82,83]$. The intestinal microflora of breast-fed infants is dominated by Bifidobacterium strains (B. breve, B. adolescentis, B. longum, and B. bifidum) (approximately $73 \%$ of all bacteria), while Bifidobacterium (approximately 31\%), Bacteroides, and Enterobacteria are typical for formula-fed infants [82,84]. Moreover, the differences in total bacteria, Enterobacteriaceae, and fecal ammonia among formula-fed infants with and without colic was reported [84].

The Bifidobacterium and Lactobacillus spp. present in the gastrointestinal tract of newborns and infants differ in their ability to utilize HMOs. Bifidobacterium infantis in comparison to Lactobacillus gasseri has a great ability to digest HMOs [85]. The genome of $B$. infantis encoded 24 glycosidases (including $2 \alpha$-sialidases and $5 \alpha$-L-fucosidases) [86]. Moreover, Bifidobacterium bifidum can release monosaccharides from HMOs, but has no ability to utilize fucose, sialic acid, and N-acetylglucosamine [87]. In contrast, Bifidobacterium breve cannot cut off monosaccharides from HMOs, but can ferment them [85,88]. Schwab and Gänzle [88] analyzed the hydrolytic activity of six strains of lactic acid bacteria-Lactobacillus acidophilus, Lactobacillus plantarum, Lactobacillus fermentum, Lactobacillus reuteri, Streptococcus thermophilus, and Leuconostoc mesenteroides subsp. cremoris-and reported that only two strains, namely L. plantarum and L. acidophilus, are able to hydrolyze sialylated HMOs, albeit with different efficiency. The hydrolytic activity of L. acidophilus and L. plantarum was observed for $3^{\prime}$-SL and 6'-SL, and additionally for 2'-FL, 3-FL and lacto- $N$-tetraose [88]. Moreover, glycosidases produced by commensal bacteria in the infant gut can in vivo produce a new, so far unknown SLN oligosaccharide structure [74].

\section{The Significance of Sialylated Structures of Human Milk}

\subsection{Sialylated Glycans of Human Milk and Psychomotor Development of Newborns and Infants}

Mammalian nerve cells, compared to other cells, exhibit a high content of sialic acid as a key component of gangliosides and neural cell adhesion molecules important during neurodevelopment. The majority of sialic acid present in the brain is associated with gangliosides $(65 \%)$ and glycoproteins $(32 \%)$, while free sialic acid constitutes less than 3\% [89,90]. The amount and distribution of sialic acid are variable during pre and postnatal brain development [91,92]. The level of GM1 and GD1a gangliosides in the human frontal lobe of the brain showed an approximately 12-15-fold increase from the 10th gestational week to the age of about five years [91]. The analysis of distribution of a radiolabeled sialic acid in the rat brain showed that $80 \%$ was located in the vicinity of synapses, and can influence the functioning of membranes in the synaptic space [93]. Later studies [59,90,92] showed that sialic acid is involved in the transmission of signals between nerve cells and enhances cognitive function such as learning performance and memory. Human milk, especially at the beginning of lactation, is rich in sialylated structures, which might be an exogenous source of sialic acid used by newborns and infants for synthesis of new sialylated molecules [32,59,94]. Ruhaak and coworkers [74] speculate that small amounts of sialic acids or HMOs-related sialic acids present in the lumen of the small intestine or colon might be absorbed into the bloodstream, across the blood-brain barrier, reaching the immature brain.

In an animal model, the impact of orally administration of free and conjugated sialic acid on learning and memory is intensively studied [92]. In neonatal pigs, dietary supplementation of formula with 3'- or 6'-sialyllactose serves as a source of sialic acid for neurologic development and enrich ganglioside-bound sialic acid in the brain, however did not affect feed intake, growth, or fecal consistency [95]. Additionally, the potential effect of dietary sialyllactose on neurodevelopment in a newborn piglet model depends on the suplementation doses. Moreover, different parts of the brain, namely corpus callosum, prefrontal cortex, and hippocampus may be differentially sensitive to dietary sialyllactose administration [89]. The learning behavior of adult rats is improved by feeding 
of sialyllactose. Similarly to pigs, the brain ganglioside and GM3 contents were significantly higher after suplementation of rats with sialyllactose [96]. Recent studies have shown that providing of sialic acid during lactation in rats, enhanced long-term potentiation compared to controls. Moreover, some cognitive outcomes showed better scores for 6 -sialyllactose supplemented rats compared to free sialic acid supplemented rats [97].

\subsection{Sialylated Glycans of Human Milk and Pathogen Adhesion}

Among the many benefits of breastfeeding, one of the major advantages is the opportunity to significantly reduce the risk of intestinal diseases, as well as ear and respiratory tract infections in infants $[34,98,99]$. Human milk oligosaccharides and glycoconjugates, namely glycoproteins and glycolipids $[70,94,100,101]$, are involved in the inhibition of pathogen adhesion to the host epithelial cells (Figure 3, Table 1) and they may act synergistically [66].

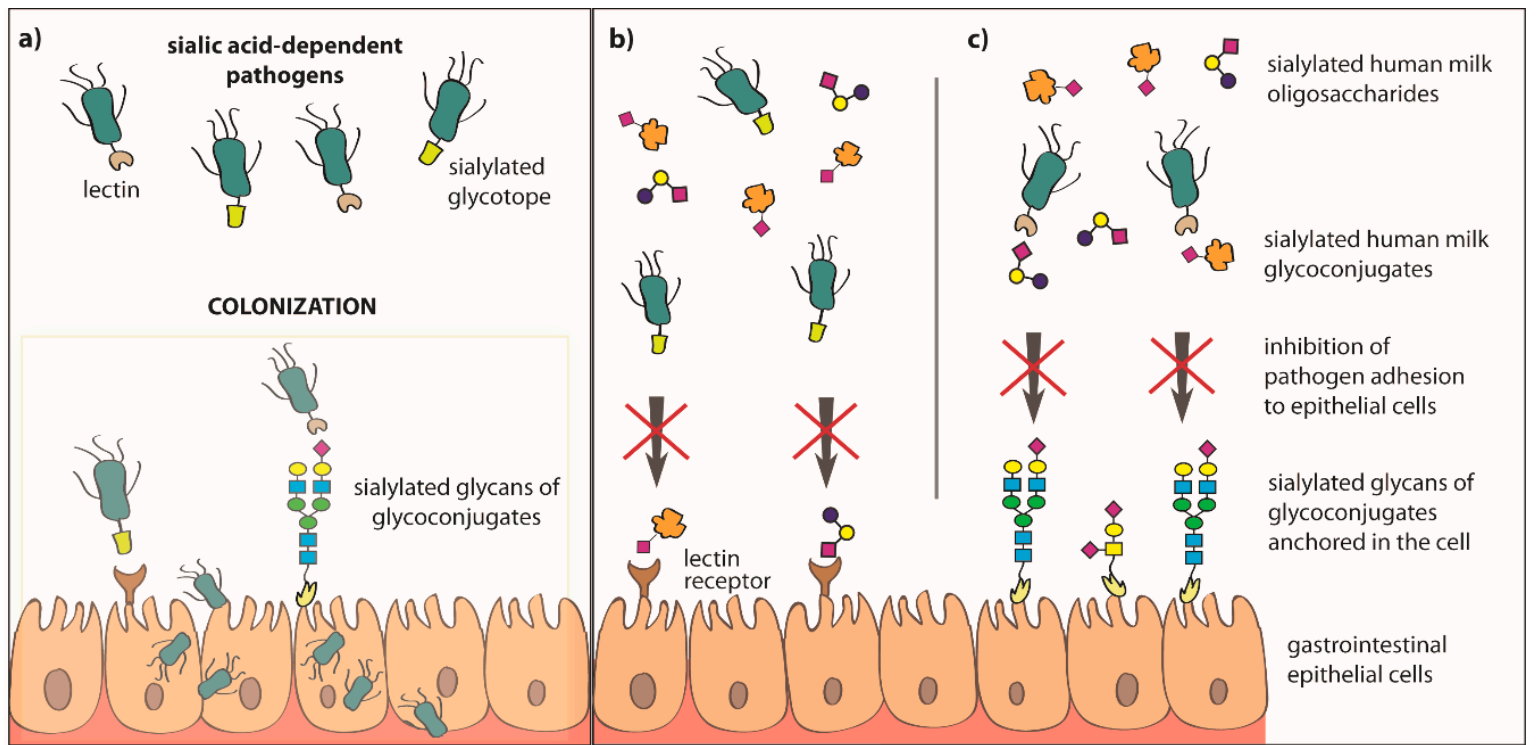

Figure 3. Inhibition of pathogen adhesion to epithelial cells of the newborn's and infant's gastrointestinal tract by sialylated oligosaccharides and glycoconjugates of human milk. The possibility of colonization of host epithelial cells by pathogens is called an invasive virulence mechanism, and in this process an important role is played by surface structures of microorganisms, such as lectin receptors and/or glycotopes (a). The process of adhesion of microorganisms to the host lectin receptor and/or glycoconjugates can be inhibited by the sialylated human milk oligosaccharides and soluble glycoconjugates, which can be recognized and bound by the lectin receptors of epithelial cells (b), and/or are recognized and bound by bacterial lectin receptors (c). In both cases, the occurrence of this type of interaction between sialylated oligosaccharides or glycoconjugates of human milk and bacterial lectin receptors and/or host cells leads to the inhibition of pathogen adhesion. 
Table 1. Sialylated glycoconjugates and oligosaccharides of human milk that may inhibit pathogen and toxin adhesion to human epithelial cells.

\begin{tabular}{|c|c|c|}
\hline Glycotope and glycoconjugate & Pathogen & References \\
\hline \multicolumn{3}{|c|}{ Human milk oligosaccharides (HMOs) } \\
\hline $\begin{array}{c}\text { Oligosaccharides with Neu5Ac } \alpha 2,3 \mathrm{Gal} \beta 1,4 \\
6^{\prime} \text {-Sialyllactose }\end{array}$ & S-fimbriated Escherichia coli & [102] \\
\hline $3^{\prime}$-Sialyllactose & Influenza virus & [103] \\
\hline $6^{\prime}$-Sialyl-N-acetyllactosamine & & \\
\hline & Human respiratory syncytial virus (RSV) & \\
\hline $3^{\prime}$-Sialyllactose & $\begin{array}{l}\text { Helicobacter pylori } \\
\text { Escherichia coli }\end{array}$ & {$[99,104,105]$} \\
\hline Sialylated human milk oligosaccharides & Enterotoxigenic and uropathogenic Escherichia coli & {$[106,107]$} \\
\hline \multicolumn{3}{|c|}{ GLYCOPROTEINS } \\
\hline Sialylated glycans of human skim milk mucins and S-IgA & S-fimbriated Escherichia coli & [108] \\
\hline Sialylated glycans of human milk glycoproteins & Helicobacter pylori & [109] \\
\hline Sialylated glycans of k-casein & Streptococcus mutans & [110] \\
\hline Sialylated glycans of lactadherin and mucins in the milk fat globule & Rotavirus & [111] \\
\hline \multicolumn{3}{|c|}{ GLYCOLIPIDS } \\
\hline GM1 & $\begin{array}{l}\text { Enterotoxigenic Escherichia coli (ETEC), } \\
\text { Heat labile-toxin of Escherichia coli (LT), } \\
\text { Cholera toxin of Vibrio cholerae (CT) }\end{array}$ & {$[70,112,113]$} \\
\hline GM1, GM2 & Vacuolating cytotoxin A of Helicobacter pylori (VacA) & {$[70,114]$} \\
\hline GM2 & Human respiratory syncytial virus (RSV) & {$[70,115]$} \\
\hline GM3 & Enterotoxigenic Escherichia coli (ETEC) & [113] \\
\hline GM1, GM3, GD3 & $\begin{array}{c}\text { Campylobacter jejuni, } \\
\text { Listeria monocytogenes, } \\
\text { Salmonella enterica (Typhi) } \\
\text { Shigella sonnei, } \\
\text { Helicobacter pylori }\end{array}$ & {$[70,116]$} \\
\hline $\begin{array}{c}\text { GD3 } \\
\text { Neu5Ac }(\alpha 2,8) \text { Neu5Ac }\end{array}$ & Enterotoxigenic Escherichia coli (ETEC) & {$[70,112]$} \\
\hline $\mathrm{Gb}_{3}$ & $\begin{array}{l}\text { Shigella dysenteriae } \\
\text { Shiga toxin (Stx) }\end{array}$ & {$[65,70,113]$} \\
\hline $\begin{array}{l}\text { Glycolipids with glycotope: } \\
\text { Neu5Ac } \alpha 2,3 \mathrm{Gal} \text {, Neu5Ac } \alpha 2,6 \mathrm{Gal}\end{array}$ & Enterovirus 71 (EV71) & {$[70,117]$} \\
\hline
\end{tabular}

GM-Monosialoganglioside; GD—Disialoganglioside; Gb—Globotriaosylceramide.

Soluble sialylated human milk oligosaccharides and glycoconjugates "rinsing" epithelial cells of the throat, esophagus, and intestines of the breastfed newborn can be recognized and bound by lectin receptors of sialic acid-dependent bacteria and/or lectin receptors of the host cells. In both cases, it leads to blocking of lectin receptors by sialylated milk molecules, which does not allow colonization of the host cells by pathogens (Figure 3) [10,34,66,118-120]. The participation of sialylated and fucosylated human milk oligosaccharides and glycoconjugates in the inhibition of pathogen adhesion to host cells is possible due to the presence on their structures of glycotopes, which are the same as or are very similar to the glycotopes of glycoconjugates present on the surface of host epithelial cells [66].

Human milk oligosaccharides elicit antimicrobial and antibiofilm activity against Streptococcus agalactiae (GBS), Staphylococcus aureus, and Acinetobacter baumanni, which are pathogens of particular interest in infant health [121-124]. As reported by Lin and coworkers [124] only neutral, non-sialylated fraction of HMOs may inhibit growth of group B Streptococcus. However, further investigation demonstrated that the five structurally defined, ubiquitous sialylated HMOs, variants of lacto-N-tetraose, exhibit antimicrobial and antibiofilm activities against Group B Streptococcus [125]. Moreover, HMOs have ability to potentiate the antibiotic activity what seem to be important as GBS has evolved high levels of resistance toward aminoglycosides, macrolides, and tetracyclines [126].

It was shown that $3^{\prime}$-SL and 2'-FL may in vitro reduce the incidence of viral infections caused by respiratory syncytial virus (RSV) by a significant decrease of RSV viral load and cytokine level in airway epithelia [99]. A similar effect was also observed for 6'-SL and LNnT for influenza viral load [99]. It has been reported that HMOs contribute to the reduced duration of rotavirus-induced diarrhea in a large animal model. Preclinical study in pigs showed that the dietary HMOs such as $2^{\prime}$-fucosyllactose, lacto-N-neotetraose, 6 '-sialyllactose, and $3^{\prime}$-sialyllactose were more effective than 
prebiotics in altering systemic and gastrointestinal immune cells and may influence on rotavirus infection susceptibility [127]. Additionally, sialylated milk oligosaccharides can reduce the infectivity of human rotaviruses in monkey kidney epithelial cells (MA104), primarily through an effect on the virus [128]. Moreover, the mixture of $3^{\prime}-\mathrm{SL}$ and $6^{\prime}-\mathrm{SL}$, at the same ratio as in breast milk, was more effective in reducing infectivity (73\% reduction) than when compared with $3^{\prime}-\mathrm{SL}$ ( $47 \%$ reduction) or 6 '-SL (40\% reduction) individually [128].

Specific interaction between sialylated glycans of S-IgA and S-fimbriated E. coli protects newborns from sepsis and meningitis caused by these pathogens [108]. Additionally, human milk S-IgA glycans are an important element that links innate and acquired immunity [44]. Moreover, sialylated glycans of human milk k-casein inhibited the binding of Streptococcus mutans GS-5 to saliva-coated hydroxyapatite [110], while sialylated glycans of milk mucins can be bound by rotavirus and inhibit its replication both in vitro and in vivo [111] (Table 1). It was also reported that Neu5Ac $\alpha 2,3 \mathrm{Gal}$ and Neu5Ac $\alpha 2,6 \mathrm{Gal}$ purified from human milk might inhibit the adhesion of enterovirus 71 to the human cell line DLD-1 [117]. Interestingly, some viruses such as coxsackie virus 24 bind preferentially to $\alpha 2,3$-sialylated glycans, in contrast to preferential binding of $\alpha 2,6$-sialylated glycans by influenza virus $[129,130]$.

The human milk fat globule membrane contains gangliosides, which also participate in protection of breastfed newborns and infants against pathogens (Table 1). However, their efficiency is different, namely GM1 showed 80\% inhibition of adhesion of enterotoxigenic strain of E. coli to the cell line Caco-2 (in vitro Caco-2 cell monolayer form functionally and structurally similar to human enterocytes), while GM3 and GD3 showed $69 \%$ and 16\% inhibition, respectively [112]. Additionally, some sialylated glycolipids of human milk may also prevent adverse effects of cholera toxin [131], Shiga toxin [65], and heat-labile enterotoxin of Escherichia coli [70,132,133] (Table 1). Moreover, GM1, GM3, and GD3 glycolipids of human milk are able to reduce the adhesion of Campylobacter jejuni, Helicobacter pylori, Listeria monocytogenes, Salmonella enterica serovar Typhi, and Shigella sonnei to Caco-2 cells $[70,116]$. In light of the above, the different types of oligosaccharides and glycans attached to glycoconjugates present in human milk seem to cooperate to provide broader protection of newborns and infants against infections [64]. Moreover, they are considered as natural prophylactic or therapeutic biomolecules, which modulate and support the immature immune system of newborns and infants.

\subsection{Sialylated HMOs and Altered Glycan-Related Gene Expression}

Sialylated oligosaccharides of human milk may also modulate the glycosylation pattern of the surface of host (newborn and infants) epithelial cells. In vitro studies showed that the addition of 3'-SL decreases the expression of glycosyltransferases (ST3Gal1, ST3Gal2, and ST3Gal4) responsible for the synthesis of $\alpha 2,3-$ and $\alpha 2,6$-sialylated glycotopes on the cell surface [134]. The reduction of sialylation of Caco-2 cells significantly inhibited the adhesion of enteropathogenic E. coli (EPEC) [23,34]. Straubinger and coworkers [135] showed that in vitro human milk oligosaccharides induce differential expression of glycan-related genes in Caco-2 cells, in contrast to synthetic galactooligosaccharides (GOS), currently added to infant formula to mimic HMOs.

\subsection{Sialylated Oligosaccharides of Human Milk as Immunomodulators}

During inflammatory processes E and P-selectin on the apical surface of endothelial cells recognize and interact with sialyl-Lewis X (sLeX) glycotopes, a part of cell-surface glycoconjugates on leukocytes, which are essential for leukocyte extravasation and mucosal infiltration $[98,136]$. Similarly, some human milk oligosaccharides might be recognized by immune receptors and in this way modulate the adhesion of cells in breastfed infants $[35,83,136,137]$. The first experimental data suggesting that HMOs interfere with leukocyte rolling and potentially reduce leukocyte extravasation has been reported by Rudloff and co-workers [77]. Based on previous findings [77,138-140], Bode and Jantscher-Krenn [35] speculate that 3 '-sialyl-3-fucosyllactose (3'-S,3-FL) present in human milk and more complex HMOs with more than one sLeX glycotope, which allows multivalent binding to selectins, can participate in 
reduction of leukocyte rolling and adhesion. Moreover, in comparison to sLeX and 3'-S,3-FL alone, the pool of all sialylated HMOs was more effective. In contrast, there was no effect on leukocyte rolling and adhesion when the simplest sialylated trisaccharides ( $3^{\prime}$-SL and $6^{\prime}$-SL) were used [35,141].

Experimental work of Bode and coworkers [138] demonstrated that sialylated HMOs reduce in vitro the ability of rolling and adhesion of leukocytes, isolated from human peripheral blood, to TNF-alpha-activated human umbilical vein endothelial cells. Additionally, a decrease of monocyte adhesion to human umbilical vein endothelial cells ranging from $24.0 \%$ to $52.8 \%$ for physiological levels of sialylated fraction of HMOs $(0.0125-0.125 \mathrm{mg} / \mathrm{L})$ was observed [138]. Moreover, sialylated HMOs have the ability to ex vivo reduce formation of platelet-neutrophil complexes, which can be more easily activated than circulating neutrophils [36,142]. In this way, the sialylated HMOs can mute immunological processes, such as capacity for phagocytosis and production of the reactive form of oxygen, which are the first steps in the development of necrotizing enterocolitis (NEC) [36,98,143,144]. Of the many sialylated oligosaccharides, an important role in reducing the frequency of occurrence of inflammatory diseases, including NEC, in breastfed infants compared to formula-fed infants is played by DS-LNT, which is one of the most abundant disialylated human milk oligosaccharides and may be used as an anti-inflammatory agent $[136,145]$. Recently, it was reported that DS-LNT concentrations were lower in breast milk from mothers with preterm infants who developed NEC [145,146]. In light of the above, the authors $[98,136,145,146]$ suggested that estimation of mother's milk DS-LNT deficiency might be helpful in identifying the increased risk for NEC development. Moreover, enzymatically sialylated galacto-oligosaccharides (Sia-GOS) together with 2'-fucosyllactose might reduce NEC in neonatal rats [145]. Additionally, HMOs added to infant formula in amounts comparable to breast milk induce limited short-term effects on the immature gut in preterm pigs [147]. Additionally, sialylated HMOs through binding to cells may prevent apoptosis [56]. However, as pointed out by authors, the results obtained in animal model, warrant further studies to investigate the underlying mechanisms and to assess safety and efficacy in human neonates.

Milk oligosaccharides affect mucosal immunity and bacterial colonization of breastfed neonates. In a rodent model, it was reported that 3'-SL directly modulates mucosal immunity by induction of inflammation through Toll-like receptor 4 (TLR4) signaling [148]. Additionally, HMOs and BMOs have the ability to modulate the transcriptional response of colonic epithelial cells (HT-29), namely they increase the level of expression of cell surface receptors, chemokines, and an epithelial cell-derived cytokine (IL-17C) and in this way may increase the protection of neonates, while also contributing to the maturation of the intestinal immune response [149]. Moreover, in a mouse model, human milk oligosaccharides such as $2^{\prime}$-fucosyllactose and 6 -sialyllactose reduce the symptoms of food allergy and may be considered as therapeutics in allergic disease [150].

\section{Sialic Acid in Infant Formulas}

An important aspect of newborn and infant feeding is the content of sialic acid in artificial milk. Formula-fed infants only obtain approximately $25 \%$ or less of the sialic acid delivered during exclusively breastfeeding; namely mature human milk contains $0.7 \mathrm{~g} / \mathrm{L}$ of sialic acid, while formula milk based on mature bovine milk contains $0-0.2 \mathrm{~g} / \mathrm{L}$ [32,110]. Moreover, a majority of sialic acid $(70 \%)$ present in formula milk is linked with glycoproteins, whereas in human milk, it is linked with HMOs (73\%) [32]. However, the absolute concentrations are quite different; namely in human milk the concentrations of sialylated HMOs and bovine milk oligosaccharides (BMOs) are $2-3 \mathrm{~g} / \mathrm{L}$ and $0.07-0.08 \mathrm{~g} / \mathrm{L}$, respectively (Table 2). Moreover, oligosaccharides of human and bovine milk due to differences in concentration and composition show quite different protection against human pathogens $[38,47,151,152]$. 
Table 2. Comparison of human and bovine milk glycoproteins and free oligosaccharides.

\begin{tabular}{|c|c|c|}
\hline \multirow[b]{2}{*}{ Glycans/Oligosaccharides } & \multicolumn{2}{|c|}{ Milk Glycoproteins } \\
\hline & $\begin{array}{c}\text { Human } \\
{[43]}\end{array}$ & $\begin{array}{c}\text { Bovine } \\
\text { [43] }\end{array}$ \\
\hline Fucosylated N-glycans & 24 out of 38 detected & 21 out of 51 detected \\
\hline Sialylated N-glycans & 12 out of 38 detected & 22 out of 51 detected \\
\hline \multirow[t]{3}{*}{ N-glycans with Neu5Gc } & not detected & 9 out of 51 detected \\
\hline & \multicolumn{2}{|c|}{ Oligosaccharides } \\
\hline & HMOs & BMOs \\
\hline Total concentration & $5-15 / 20 \mathrm{~g} / \mathrm{L}[34,98]$ & $0.05-0.01 \mathrm{~g} / \mathrm{L}[34,42,98]$ \\
\hline Identified structures & $>200[38]$ & $\sim 40[34,70]$ \\
\hline Identifled structures & $>150[136]$ & $20[151]$ \\
\hline Nonfucosylated neutral & $42-55 \%[56]$ & $14 \%[151]$ \\
\hline Fucosylated oligosaccharides & $\begin{array}{c}35-50 \% \text { [56] } \\
60-80 \% \text { [47] } \\
(\sim 7-16 \mathrm{~g} / \mathrm{L})\end{array}$ & $\begin{array}{c}\sim 1 \%[34,151] \\
(\sim 0.0005 \mathrm{~g} / \mathrm{L})\end{array}$ \\
\hline & $12-14 \%[56]$ & $70 \%[34,38]$ \\
\hline Sialylated oligosaccharides & $\begin{array}{l}10-15 \%[47] \\
(2-3 \mathrm{~g} / \mathrm{L}) *\end{array}$ & $\begin{array}{c}84 \% \text { [151] } \\
(0.035-0.042 \mathrm{~g} / \mathrm{L})\end{array}$ \\
\hline $\begin{array}{c}\text { Presence of Neu5Gc } \\
\text { (xeno-autoantigen) }\end{array}$ & not detected & $\begin{array}{c}5 \%[38] \\
2 \%[151]\end{array}$ \\
\hline
\end{tabular}

* calculated from available data for both lower and higher values of the range. HMOs-Human Milk Oligosaccharides, BMOs—-Bovine Milk Oligosaccharides.

The comparison of N-glycome of human and bovine milk glycoproteins using high performance liquid chromatography and tandem mass spectrometry showed that 12 out of the 38 detected human milk N-glycans were sialylated, while for bovine milk N-glycans 22 out of 51 were sialylated (Table 2) [43]. Another important aspect is the presence of N-glycolyl-5-neuraminic acid (Neu5Gc) in bovine milk and thus in bovine-based formula milk, which does not naturally occur in human milk $[32,59,153]$. Humans are genetically deprived of the ability to synthesize Neu5Gc due to the lack of an active monooxygenase (exon deletions and/or mutations causing a frameshift in the gene CMAH) $[15,19,154,155]$. Neu5Gc is a derivative of sialic acid, which is formed by hydroxylation of the $\mathrm{N}$-acetyl group at C5 of Neu5Ac $[15,19,154,155]$.

Neu5Gc is classified as a xeno-autoantigen, which can be delivered with red meat and bovine milk or can be synthesized as the end product of abnormal changes of fatty acids $[153,156,157]$. Moreover, Neu5Gc is not discriminated from Neu5Ac by biochemical metabolic pathways, which can lead to the incorporation of Neu5Gc to newly synthesized glycoconjugates [154]. Glycans decorated with Neu5Gc present on the cell surface may induce the synthesis of anti-Neu5Gc antibodies (called Hanganutziu-Deicher antibodies). The formation of such antigen-antibody complexes might provoke a chronic inflammatory process, which can potentially trigger carcinogenesis [154]. The content of Neu5Gc in bovine-based formula milk is about $~ 3-5 \%$ of the total sialic acid, however, further research is needed to investigate the impact of formula milk-derived Neu5Gc on the health and development of newborns and infants $[158,159]$.

\section{Sialic Acid in Milk from Milk Bank}

Human milk in the intensive care unit for preterm newborns is used not only as a nutrient, but also as the first and the best natural medicine [160]. In some cases when the mother's own milk is not available, milk deposited by donors in a milk bank can be used. However, the milk collected in a milk bank must be processed by methods, which do not affect the biologically active milk components but are effective in the neutralization of pathogens, to be safe for newborns. A small body of work has examined the effects of pasteurization on the macronutrient and immune-protective protein concentration in donor milk [161-163]. To date, only two reports, by Meredith-Dennis and 
coworkers [162] and Daniels and coworkers [164], have analyzed the impact of pasteurization on HMOs content in banked milk. Use of the Holder pasteurization technique to process donor milk for storage is more favorable for biologically active HMOs containing fucose and sialic acid than retort sterilization [162]. However, this issue requires further investigation.

\section{Mimicking Human Milk}

Milk produced by no other mammal species has similar quantity and diversity of oligosaccharides and glycoconjugates compared to human milk [34,38,165]. However, when breastfeeding is not possible, as a substitute of human milk, formula milk mixtures are used. On the market, two main types of formula milk-mixtures based on bovine milk and mixtures with modified composition of proteins (isolated and hydrolyzed bovine milk proteins)—are available. The majority of human milk oligosaccharides and glycoconjugates such as glycoproteins and glycolipids, showing a protective effect, are not found in bovine milk or protein isolates [59]. For this reason, plant-derived or synthetic prebiotic mixtures of fructooligosaccharides (oligomers of fructose built from two to more than 60 fructose unit and glucose at the reducing end) (FOS) and galactooligosaccharides (oligomers of galactose built from 3 to 10 galactose unit and glucose at the reducing end) (GOS) (the ratio of GOS:FOS is 9:1), which mimic the prebiotic properties of HMOs and support the development of beneficial intestinal microflora, can be added $[165,166]$. However, GOS and FOS, in contrast to HMOs, do not contain fucose and sialic acid residues, which can be recognized and bound by lectin receptors of sialic acid and fucose-dependent pathogens [34]. Nevertheless, despite the structural differences between HMOs and oligosaccharides such as GOS and FOS, it was reported that formula milk with addition of a mixture of GOS and FOS reduces the occurrence of atopic dermatitis [167], allergic manifestations and infections [168], and also influences the microbiota composition in the infant's feces and provides softer stools [169].

Another solution to narrowing the compositional gap between human milk and formula milk is the supplementation of infant formula with commercially available free oligosaccharides $[56,170]$. Thus far, Weichert and coworkers [170] have showed that biotechnologically synthesized oligosaccharides such as 2'-FL and 3-FL effectively inhibit in vitro the adhesion of fucose-dependent pathogens, thus reducing the risk of infection. However, due to the huge technical challenge to synthesize oligosaccharide structures identical to those in human milk, so far only relatively simple structures of oligosaccharides have been obtained on an industrial scale in this way [171]. The latest research by Guo and coworkers [172] reported the method for enzymatic synthesis of a dominant sialylated HMO, namely $6^{\prime}$-SL. It is a milestone, especially considering that traditional chemical synthesis of nine-carbon sialic acids is rather complicated and requires multiple protection and deprotection steps to achieve a specific glycosidic bond [172]. The research currently carried out worldwide paves the way for large-scale synthesis of fucosylated and sialylated oligosaccharides, whose production in the future will make a significant contribution to the food and pharmaceutical industries.

An alternative method of sourcing oligosaccharides is their extraction from animal milk, which can be potentially used in medical and functional foods [173]. Theoretically, another option to obtain HMOs is their isolation from human milk. However, it seems more reasonable to provide the "whole" milk of donor mothers than only "one" fraction isolated.

\section{Conclusions}

Mother's milk not only has nutritional value but also provides a wide range of biologically active components, which are adapted to meet the needs of newborns and infants. Glycoconjugates and free oligosaccharides unique for human milk are classified as an essential element of innate immunity delivered by the mother, which modulate and enhance the immature newborns. 
Studies of recent years indicate that, similar to fucosylated, the sialylated free oligosaccharides as well as glycans attached to proteins and lipids are a key component which, acting locally in the intestine, protects infants from infections and has an impact on the shaping of the intestinal microbiome. Additionally, sialylated oligosaccharides modulate the immunological system of newborns at a cellular level, and are crucial for brain development and probably for newborn and infant growth. Moreover, some human milk sialylated structures are considered as natural prophylactic or therapeutic biomolecules, particularly for preterm newborns. However, it should be pointed out that most of the conclusions on the immune effects are based on in vitro studies, many of which use adult cells.

In light of the above, human milk has a beneficial impact and an advantage over infant formula, which do not provide adequate immunological protection for the developing infants. For the sake of the healthy development of future generations and as a pressing global health goal, feeding newborns with their own mother's milk or with milk from donor mothers as a gold standard should be supported.

Author Contributions: J.L.-K.--review of the literature, preparing the manuscript, final approval, M.O.-P.-review of the literature, preparing the manuscript, final approval.

Funding: This research was funded by the Medical Faculty, Wrocław Medical University, Poland, grant number STM.A070.17.060.

Conflicts of Interest: The authors declare no conflict of interest.

\section{Abbreviations}

$\begin{array}{ll}\text { 2'-/3-FL } & \text { 2'-/3-fucosyllactose } \\ \text { 3'-/6'-SL } & 3^{\prime} \text {-/6'-sialyllactose } \\ \text { 3'-S,3-FL 3' } & \text { sialyl-3-fucosyllactose } \\ \text { 6'-SLN } & 6^{\prime} \text {-sialyllactosamine } \\ \text { AGP } & \alpha 1 \text {-acid glycoprotein } \\ \text { BMOs } & \text { Bovine milk oligosaccharides } \\ \text { DS-LNT } & \text { Disialyllacto-N-tetraose } \\ \text { FN } & \text { Fibronectin } \\ \text { FOS } & \text { Fructooligosaccharides } \\ \text { Fuc } & \text { Fucose } \\ \text { Gal } & \text { Galactose } \\ \text { GalNAc } & \text { N-Acetylgalactosamine } \\ \text { GD } & \text { Disialoganglioside } \\ \text { Gb } & \text { Globotriaosylceramide } \\ \text { GM } & \text { Monosialoganglioside } \\ \text { GOS } & \text { Galactooligosaccharides } \\ \text { HMOs } & \text { Human milk oligosaccharides } \\ \text { IgG } & \text { Immunoglobulin G } \\ \text { LBSA } & \text { Lipid-bound sialic acid } \\ \text { LF } & \text { Lactoferrin } \\ \text { LNFP-I } & \text { Lacto-N-fucopentaose I } \\ \text { LNnT } & \text { Lacto-N-neotetraose } \\ \text { LST } & \text { Lacto-N-tetraoses } \\ \text { NEC } & \text { Necrotizing enterocolitis } \\ \text { Neu5Ac } & \text { N-Acetylneuraminic acid (sialic acid) } \\ \text { Neu5Gc } & \text { N-glycolyl-5-neuraminic acid } \\ \text { RSV } & \text { Respiratory syncytial virus } \\ \text { Sia-GOS } & \text { sialylated galacto-oligosaccharides } \\ \text { S-IgA } & \text { Secretory immunoglobulin A } \\ \text { sLeX } & \text { sialyl-Lewis X } \\ & \end{array}$




\section{References}

1. Broadhurst, M.; Beddis, K.; Black, J.; Henderson, H.; Nair, A.; Wheeler, T. Effect of gestation length on the levels of five innate defence proteins in human milk. Early Hum. Dev. 2015, 91, 7-11. [CrossRef] [PubMed]

2. Lis-Kuberka, J.; Orczyk-Pawiłowicz, M.; Królak-Olejnik, B.; Berghausen-Mazur, M.; Barańska, K.; Katnik-Prastowska, I. Lectin-based analysis of human milk immunoglobulin $\mathrm{G}$ fucosylated variants in relation to milk maturation and perinatal risk factors. J. Appl. Biomed. 2018, 16, 232-240. [CrossRef]

3. Lis-Kuberka, J.; Kątnik-Prastowska, I.; Berghausen-Mazur, M.; Orczyk-Pawiłowicz, M. Lectin-based analysis of fucosylated glycoproteins of human skim milk during 47 days of lactation. Glycoconj. J. 2015, 32, 665-674. [CrossRef]

4. Orczyk-Pawiłowicz, M.; Hirnle, L.; Berghausen-Mazur, M.; Kątnik-Prastowska, I.M. Lactation stage-related expression of sialylated and fucosylated glycotopes of human milk $\alpha$-1-acid glycoprotein. Breastfeed. Med. 2014, 9, 313-319. [CrossRef] [PubMed]

5. Orczyk-Pawiłowicz, M.; Hirnle, L.; Berghausen-Mazur, M.; Kątnik-Prastowska, I.M. Terminal glycotope expression on milk fibronectin differs from plasma fibronectin and changes over lactation. Clin. Biochem. 2015, 48, 167-173. [CrossRef]

6. Fujimori, M.; França, E.L.; Fiorin, V.; Morais, T.C.; Honorio-França, A.C.; de Abreu, L.C. Changes in the biochemical and immunological components of serum and colostrum of overweight and obese mothers. BMC Pregnancy Childbirth 2015, 15, 166. [CrossRef] [PubMed]

7. Smilowitz, J.T.; O'Sullivan, A.; Barile, D.; German, J.B.; Lönnerdal, B.; Slupsky, C.M. The human milk metabolome reveals diverse oligosaccharide profiles. J. Nutr. 2013, 143, 1709-1718. [CrossRef] [PubMed]

8. França, E.L.; Nicomedes, T.R.; Calderon, I.M.; França, A.C.H. Time-dependent alterations of soluble and cellular components in human milk. Biol. Rhythm Res. 2010, 5, 333-347. [CrossRef]

9. Mitoulas, L.R.; Kent, J.C.; Cox, D.B.; Owens, R.A.; Sherriff, J.L.; Hartmann, P.E. Variation in fat, lactose and protein in human milk over $24 \mathrm{~h}$ and throughout the first year of lactation. Br. J. Nutr. 2002, 88, 29-37. [CrossRef]

10. Eidelman, A.I. Breastfeeding and the use of human milk: An analysis of the American Academy of Pediatrics. Breastfeeding Policy Statement. Breastfeed. Med. 2012, 7, 323-324. [CrossRef]

11. ESPGHAN Committee on Nutrition; Agostoni, C.; Braegger, C.; Decsi, T.; Kolacek, S.; Koletzko, B.; Michaelsen, K.F.; Mihatsch, W.; Moreno, L.A.; Puntis, J.; et al. Breast-feeding: A commentary by the ESPGHAN Committee on Nutrition. J. Pediatr. Gastroenterol. Nutr. 2009, 49, 112-125. [CrossRef] [PubMed]

12. World Health Organization. Available online: http://www.who.int/maternal_child_adolescent/ documents/infant_feeding/en/ (accessed on 24 January 2019).

13. Katnik-Prastowska, I. Structure and biology of sialic acids. Adv. Clin. Exp. Med. 2003, 12, 653-663.

14. Schauer, R. Achievements and challenges of sialic acid research. Glycoconj. J. 2000, 17, 485-499. [CrossRef] [PubMed]

15. Varki, A. Sialic acids in human health and disease. Trends Mol. Med. 2008, 14, 351-360. [CrossRef] [PubMed]

16. Gabius, H.J.; Siebert, H.C.; André, S.; Jiménez-Barbero, J.; Rüdiger, H. Chemical biology of the sugar code. ChemBioChem 2004, 5, 740-764. [CrossRef] [PubMed]

17. Wang, B. Sialic acid is an essential nutrient for brain development and cognition. Annu. Rev. Nutr. 2009, 29, 177-222. [CrossRef] [PubMed]

18. Park, E.I.; Manzella, S.M.; Baenziger, J.U. Rapid clearance of sialylated glycoproteins by the asialoglycoprotein receptor. J. Biol. Chem. 2003, 278, 4597-4602. [CrossRef]

19. Schauer, R. Sialic acids as regulators of molecular and cellular interactions. Curr. Opin. Struct. Biol. 2009, 19, 507-514. [CrossRef]

20. Varki, A.; Gagneux, P. Multifarious roles of sialic acids in immunity. Ann. N. Y. Acad. Sci. 2012, 1253, 16-36. [CrossRef]

21. Janas, T.; Janas, T. Membrane oligo- and polysialic acids. Biochim. Biophys. Acta 2011, 1808, $2923-2932$. [CrossRef]

22. Yabe, U.; Sato, C.; Matsuda, T.; Kitajima, K. Polysialic acid in human milk. CD36 is a new member of mammalian polysialic acid-containing glycoprotein. J. Biol. Chem. 2003, 278, 13875-13880. [CrossRef]

23. Angata, K.; Fukuda, M. Roles of polysialic acid in migration and differentiation of neural stem cells. Methods Enzymol. 2010, 479, 25-36. [CrossRef] 
24. Cerná, A.; Janega, P.; Martanovic, P.; Lisý, M.; Babál, P. Changes in sialic acid expression in the lung during intrauterine development of the human fetus. Acta Histochem. 2002, 104, 339-342. [CrossRef]

25. Ohtsubo, K.; Marth, J.D. Glycosylation in cellular mechanisms of health and disease. Cell 2006, 126, 855-867. [CrossRef]

26. Martin, M.J.; Muotri, A.; Gage, F.; Varki, A. Human embryonic stem cells express an immunogenic nonhuman sialic acid. Nat. Med. 2005, 11, 228-232. [CrossRef] [PubMed]

27. Kawai, Y.; Takemoto, M.; Oda, Y.; Kakehi, K.; Ohta, Y.; Yamaguchi, S.; Miyake, M. Inhibition of in vitro fertilization of mouse gametes by sulfated sialic acid polymers. Biol. Pharm. Bull. 2000, 23, 936-940. [CrossRef] [PubMed]

28. Miura, T.; Nelson, D.P.; Schermerhorn, M.L.; Shin'oka, T.; Zund, G.; Hickey, P.R.; Neufeld, E.J.; Mayer, J.E., Jr. Blockade of selectin-mediated leukocyte adhesion improves postischemic function in lamb hearts. Ann. Thorac. Surg. 1996, 62, 1295-1300. [CrossRef]

29. Meesmann, H.M.; Fehr, E.M.; Kierschke, S.; Herrmann, M.; Bilyy, R.; Heyder, P.; Blank, N.; Krienke, S.; Lorenz, H.M.; Schiller, M. Decrease of sialic acid residues as an eat-me signal on the surface of apoptotic lymphocytes. J. Cell Sci. 2010, 123, 3347-3356. [CrossRef] [PubMed]

30. Huang, Y.L.; Chassard, C.; Hausmann, M.; von Itzstein, M.; Hennet, T. Sialic acid catabolism drives intestinal inflammation and microbial dysbiosis in mice. Nat. Commun. 2015, 6, 8141. [CrossRef]

31. Martín-Sosa, S.; Martín, M.J.; García-Pardo, L.A.; Hueso, P. Distribution of sialic acids in the milk of spanish mothers of full term infants during lactation. J. Pediatr. Gastroenterol. Nutr. 2004, 39, 499-503. [CrossRef] [PubMed]

32. Wang, B.; Brand-Miller, J.; McVeagh, P.; Petocz, P. Concentration and distribution of sialic acid in human milk and infant formulas. Am. J. Clin. Nutr. 2001, 74, 510-515. [CrossRef] [PubMed]

33. Lis-Kuberka, J.; Berghausen-Mazur, M.; Orczyk-Pawiłowicz, M. Alpha 2,3- and alpha 2,6-sialylation of human skim milk glycoproteins during milk maturation. J. Appl. Biomed. 2017, 3, 196-203. [CrossRef]

34. Bode, L. Human milk oligosaccharides: Every baby needs a sugar mama. Glycobiology 2012, 22, 1147-1162. [CrossRef] [PubMed]

35. Bode, L.; Jantscher-Krenn, E. Structure-function relationships of human milk oligosaccharides. Adv. Nutr. 2012, 3, 383S-391S. [CrossRef]

36. Bode, L.; Rudloff, S.; Kunz, C.; Strobel, S.; Klein, N. Human milk oligosaccharides reduce platelet-neutrophil complex formation leading to a decrease in neutrophil $\beta 2$ integrin expression. J. Leukoc. Biol. 2004, 76, 820-826. [CrossRef] [PubMed]

37. Kunz, C.; Rudloff, S.; Baier, W.; Klein, N.; Strobel, S. Oligosaccharides in human milk: Structural, functional, and metabolic aspects. Annu. Rev. Nutr. 2000, 20, 699-722. [CrossRef]

38. Urashima, T.; Taufik, E.; Fukuda, K.; Asakuma, S. Recent advances in studies on milk oligosaccharides of cows and other domestic farm animals. Biosci. Biotechnol. Biochem. 2013, 77, 455-466. [CrossRef]

39. Urashima, T.; Hirabayashi, J.; Sato, S.; Kobata, A. Human milk oligosaccharides as essential tools for basic and application studies on galectins. Trends Glycosci. Glycotechnol. 2018, 30, SE51-SE65. [CrossRef]

40. Rudloff, S.; Obermeier, S.; Borsch, C.; Hartmann, R.; Brösicke, H.; Lentze, M.J.; Kunz, C. Incorporation of orally applied (13)C-galactose into milk lactose and oligosaccharides. Glycobiology 2006, 16, 477-487. [CrossRef]

41. Smilowitz, J.T.; Lebrilla, C.B.; Mills, D.A.; German, J.B.; Freeman, S.L. Breast milk oligosaccharides: Structure-function relationships in the neonate. Annu. Rev. Nutr. 2014, 34, 143-169. [CrossRef]

42. Kirmiz, N.; Robinson, R.C.; Shah, I.M.; Barile, D.; Mills, D.A. Milk glycans and their interaction with the infant-gut microbiota. Annu. Rev. Food Sci. Technol. 2018, 9, 429-450. [CrossRef] [PubMed]

43. Nwosu, C.C.; Aldredge, D.L.; Lee, H.; Lerno, L.A.; Zivkovic, A.M.; German, J.B.; Lebrilla, C.B. Comparison of the human and bovine milk N-glycome via high-performance microfluidic chip liquid chromatography and tandem mass spectrometry. J. Proteome Res. 2012, 11, 2912-2924. [CrossRef] [PubMed]

44. Royle, L.; Roos, A.; Harvey, D.J.; Wormald, M.R.; van Gijlswijk-Janssen, D.; el Redwan, R.M.; Wilson, I.A.; Daha, M.R.; Dwek, R.A.; Rudd, P.M. Secretory IgA N- and O-glycans provide a link between the innate and adaptive immune systems. J. Biol. Chem. 2003, 278, 20140-20153. [CrossRef] [PubMed]

45. Coppa, G.V.; Pierani, P.; Zampini, L.; Carloni, I.; Carlucci, A.; Gabrielli, O. Oligosaccharides in human milk during different phases of lactation. Acta Paediatr. Suppl. 1999, 88, 89-94. [CrossRef] [PubMed] 
46. Xu, G.; Davis, J.C.; Goonatilleke, E.; Smilowitz, J.T.; German, J.B.; Lebrilla, C.B. Absolute quantitation of human milk oligosaccharides reveals phenotypic variations during lactation. J. Nutr. 2017, 147, 117-124. [CrossRef] [PubMed]

47. De Leoz, M.L.; Gaerlan, S.C.; Strum, J.S.; Dimapasoc, L.M.; Mirmiran, M.; Tancredi, D.J.; Smilowitz, J.T.; Kalanetra, K.M.; Mills, D.A.; German, J.B.; et al. Lacto-N-tetraose, fucosylation, and secretor status are highly variable in human milk oligosaccharides from women delivering preterm. J. Proteome Res. 2012, 11, 4662-4672. [CrossRef] [PubMed]

48. Morrow, A.L.; Chen, C.; Cline, A.; Newburg, D.S. Human milk oligosaccharides in preterm and term milk. FASEB J. 2016, 30, 673.10. [CrossRef]

49. Kunz, C.; Meyer, C.; Collado, M.C.; Geiger, L.; García-Mantrana, I.; Bertua-Ríos, B.; Martínez-Costa, C.; Borsch, C.; Rudloff, S. Influence of gestational age, secretor and Lewis blood group status on the oligosaccharide content of human milk. J. Pediatr. Gastroenterol. Nutr. 2017, 64, 789-798. [CrossRef]

50. Kumazaki, T.; Yoshida, A. Biochemical evidence that secretor gene, Se, is a structural gene encoding a specific fucosyltransferase. Proc. Natl. Acad. Sci. USA 1984, 81, 4193-4197. [CrossRef]

51. Stahl, B.; Thurl, S.; Henker, J.; Siegel, M.; Finke, B.; Sawatzki, G. Detection of four human milk groups with respect to Lewis-blood-group-dependent oligosaccharides by serologic and chromatographic analysis. Adv. Exp. Med. Biol. 2001, 501, 299-306.

52. Thurl, S.; Munzert, M.; Henker, J.; Boehm, G.; Müller-Werner, B.; Jelinek, J.; Stahl, B. Variation of human milk oligosaccharides in relation to milk groups and lactational periods. Br. J. Nutr. 2010, 104, 1261-1271. [CrossRef] [PubMed]

53. Totten, S.M.; Zivkovic, A.M.; Wu, S.; Ngyuen, U.; Freeman, S.L.; Ruhaak, L.R.; Darboe, M.K.; German, J.B.; Prentice, A.M.; Lebrilla, C.B. Comprehensive profiles of human milk oligosaccharides yield highly sensitive and specific markers for determining secretor status in lactating mothers. J. Proteome Res. 2012, 11, 6124-6133. [CrossRef] [PubMed]

54. Ninonuevo, M.R.; Park, Y.; Yin, H.; Zhang, J.; Ward, R.E.; Clowers, B.H.; German, J.B.; Freeman, S.L.; Killeen, K.; Grimm, R.; et al. A strategy for annotating the human milk g lycome. J. Agric. Food Chem. 2006, 54, 7471-7480. [CrossRef] [PubMed]

55. Ninonuevo, M.R.; Perkins, P.D.; Francis, J.; Lamotte, L.M.; LoCascio, R.G.; Freeman, S.L.; Mills, D.A.; German, J.B.; Grimm, R.; Lebrilla, C.B. Daily variations in oligosaccharides of human milk determined by microfluidic chips and mass spectrometry. J. Agric. Food Chem. 2008, 56, 618-626. [CrossRef] [PubMed]

56. Donovan, S.M.; Comstock, S.S. Human Milk Oligosaccharides Influence Neonatal Mucosal and Systemic Immunity. Ann. Nutr. Metab. 2016, 69, 41-51. [CrossRef] [PubMed]

57. Charbonneau, M.R.; O’Donnell, D.; Blanton, L.V.; Totten, S.M.; Davis, J.C.; Barratt, M.J.; Cheng, J.; Guruge, J.; Talcott, M.; Bain, J.R.; et al. Sialylated milk oligosaccharides promote microbiota-dependent growth in models of infant undernutrition. Cell 2016, 164, 859-871. [CrossRef] [PubMed]

58. Thurl, S.; Munzert, M.; Boehm, G.; Matthews, C.; Stahl, B. Systematic review of the concentrations of oligosaccharides in human milk. Nutr. Rev. 2017, 75, 920-933. [CrossRef]

59. Wang, B.; Brand-Miller, J. The role and potential of sialic acid in human nutrition. Eur. J. Clin. Nutr. 2003, 57, 1351-1369. [CrossRef]

60. Sprenger, N.; Lee, L.Y.; De Castro, C.A.; Steenhout, P.; Thakkar, S.K. Longitudinal change of selected human milk oligosaccharides and association to infants' growth, an observatory, single center, longitudinal cohort study. PLoS ONE 2017, 12, e0171814. [CrossRef]

61. McGuire, M.K.; Meehan, C.L.; McGuire, M.A.; Williams, J.E.; Foster, J.; Sellen, D.W.; Kamau-Mbuthia, E.W.; Kamundia, E.W.; Mbugua, S.; Moore, S.E.; et al. What's normal? Oligosaccharide concentrations and profiles in milk produced by healthy women vary geographically. Am. J. Clin. Nutr. 2017, 105, 1086-1100. [CrossRef]

62. Groër, M.; Davis, M.; Casey, K.; Short, B.; Smith, K.; Groër, S. Neuroendocrine and immune relationships in postpartum fatigue. MCN Am. J. Matern. Child. Nurs. 2005, 30, 133-138. [CrossRef] [PubMed]

63. Bode, L.; Beermann, C.; Mank, M.; Kohn, G.; Boehm, G. Human and bovine milk gangliosides differ in their fatty acid composition. J. Nutr. 2004, 134, 3016-3020. [CrossRef] [PubMed]

64. Newburg, D.S. Glycobiology of human milk. Biochemistry 2013, 78, 771-785. [CrossRef] [PubMed]

65. Newburg, D.S.; Chaturvedi, P. Neutral glycolipids of human and bovine milk. Lipids 1992, 27, 923-927. [CrossRef] [PubMed] 
66. Newburg, D.S.; Grave, G. Recent advances in human milk glycobiology. Pediatr. Res. 2014, 75, 675-679. [CrossRef] [PubMed]

67. Pan, X.L.; Izumi, T. Variation of the ganglioside compositions of human milk, cow's milk and infant formulas. Early Hum. Dev. 2000, 57, 25-31. [CrossRef]

68. Giuffrida, F.; Elmelegy, I.M.; Thakkar, S.K.; Marmet, C.; Destaillats, F. Longitudinal evolution of the concentration of gangliosides GM3 and GD3 in human milk. Lipids 2014, 49, 997-1004. [CrossRef]

69. Nakano, T.; Sugawara, M.; Kawakami, H. Sialic acid in human milk: Composition and functions. Acta Paediatr. Taiwan 2001, 42, 11-17.

70. Peterson, R.; Cheah, W.Y.; Grinyer, J.; Packer, N. Glycoconjugates in human milk: Protecting infants from disease. Glycobiology 2013, 23, 1425-1438. [CrossRef]

71. Karim, M.; Wang, B. Is sialic acid in milk food for the brain? CAB Rev. Perspect. Agric. Vet. Sci. Nutr. Nat. Resour. 2006, 1, 18-29. [CrossRef]

72. Nohle, U.; Schauer, R. Uptake, metabolism and excretion of orally and intravenously administered, 14C-and $3 \mathrm{H}$-labeled nacetylneuraminic acid mixture in the mouse and rat. Hoppe Seylers Z. Physiol. Chem. 1981, 362, 1495-5106. [CrossRef] [PubMed]

73. Downing, J.A.; Wilkinson, S.J.; Wang, B.; Brand-Miller, J.; Bryden, W.L. Uptake of N-acetylneuraminic acid-6-14C (sialic acid) into the brain of neonatal piglets. Asia Pac. Clin. Nutr. 2001, 25, S39.

74. Ruhaak, L.R.; Stroble, C.; Underwood, M.A.; Lebrilla, C.B. Detection of milk oligosaccharides in plasma of infants. Anal. Bioanal. Chem. 2014, 406, 5775-5784. [CrossRef] [PubMed]

75. Goehring, K.C.; Kennedy, A.D.; Prieto, P.A.; Buck, R.H. Direct evidence for the presence of human milk oligosaccharides in the circulation of breastfed infants. PLoS ONE 2014, 9, e101692. [CrossRef] [PubMed]

76. De Leoz, M.L.; Wu, S.; Strum, J.S.; Niñonuevo, M.R.; Gaerlan, S.C.; Mirmiran, M.; German, J.B.; Mills, D.A.; Lebrilla, C.B.; Underwood, M.A. A quantitative and comprehensive method to analyze human milk oligosaccharide structures in the urine and feces of infants. Anal. Bioanal. Chem. 2013, 405, 4089-4105. [CrossRef] [PubMed]

77. Rudloff, S.; Pohlentz, G.; Borsch, C.; Lentze, M.J.; Kunz, C. Urinary excretion of in vivo 13C-labelled milk oligosaccharides in breastfed infants. Br. J. Nutr. 2012, 107, 957-963. [CrossRef] [PubMed]

78. Yamamoto, K. Biological analysis of the microbial metabolism of hetero-oligosaccharides in application to glycotechnology. Biosci. Biotechnol. Biochem. 2012, 76, 1815-1827. [CrossRef]

79. Jantsher-Krenn, E.; Marx, C.; Bode, L. Human milk oligosaccharides are differentially metabolized in neonatal rats. Br. J. Nutr. 2013, 110, 640-650. [CrossRef]

80. Vazquez, E.; Santos-Fandila, A.; Buck, R.; Rueda, R.; Ramirez, M. Major human milk oligosaccharides are absorbed into the systemic circulation after oral administration in rats. Br. J. Nutr. 2017, 117, 237-247. [CrossRef]

81. De Leoz, M.L.; Kalanetra, K.M.; Bokulich, N.A.; Strum, J.S.; Underwood, M.A.; German, J.B.; Mills, D.A.; Lebrilla, C.B. Human milk glycomics and gut microbial genomics in infant feces show a correlation between human milk oligosaccharides and gut microbiota: A proof-of-concept study. J. Proteome Res. 2015, 14, 491-502. [CrossRef]

82. Bezirtzoglou, E.; Tsiotsias, A.; Welling, G.W. Microbiota profile in feces of breast- and formula-fed newborns by using fluorescence in situ hybridization (FISH). Anaerobe 2011, 17, 478-482. [CrossRef] [PubMed]

83. Klein, N.; Schwertmann, A.; Peters, M.; Kunz, C.; Strobel, S. Immunomodulatory effects of breast milk oligosaccharides. Adv. Exp. Med. Biol. 2000, 478, 251-259.

84. Savino, F.; Quartieri, A.; De Marco, A.; Garro, M.; Amaretti, A.; Raimondi, S.; Simone, M.; Rossi, M. Comparison of formula-fed infants with and without colic revealed significant differences in total bacteria, Enterobacteriaceae and faecal ammonia. Acta Paediatr. 2017, 106, 573-578. [CrossRef] [PubMed]

85. Ward, R.E.; Niñonuevo, M.; Mills, D.A.; Lebrilla, C.B.; German, J.B. In vitro fermentability of human milk oligosaccharides by several strains of bifidobacteria. Mol. Nutr. Food Res. 2007, 51, 1398-1405. [CrossRef]

86. Underwood, M.A.; German, J.B.; Lebrilla, C.B.; Mills, D.A. Bifidobacterium longum subspecies infantis: Champion colonizer of the infant gut. Pediatr. Res. 2015, 77, 229-235. [CrossRef] [PubMed]

87. Sela, D.A.; Li, Y.; Lerno, L.; Wu, S.; Marcobal, A.M.; German, J.B.; Chen, X.; Lebrilla, C.B.; Mills, D.A. An infant-associated bacterial commensal utilizes breast milk sialyloligosaccharides. J. Biol. Chem. 2011, 286, 11909-11918. [CrossRef] [PubMed] 
88. Schwab, C.; Gänzle, M. Lactic acid bacteria fermentation of human milk oligosaccharide components, human milk oligosaccharides and galactooligosaccharides. FEMS Microbiol. Lett. 2011, 315, 141-148. [CrossRef] [PubMed]

89. Mudd, A.T.; Fleming, S.A.; Labhart, B.; Chichlowski, M.; Berg, B.M.; Donovan, S.M.; Dilger, R.N. Dietary sialyllactose influences sialic acid concentrations in the prefrontal cortex and magnetic resonance imaging measures in corpus callosum of young pigs. Nutrients 2017, 9, 1297. [CrossRef]

90. Wang, B. Molecular mechanism underlying sialic acid as an essential nutrient for brain development and cognition. Adv. Nutr. 2012, 3, 465S-472S. [CrossRef]

91. Svennerholm, L.; Bostrom, K.; Fredman, P.; Mansson, J.E.; Rosengren, B.; Rynmark, B.M. Human brain gangliosides: Developmental changes from early fetal stage to advanced age. Biochim. Biophys. Acta 1989, 1005, 109-117. [CrossRef]

92. Wang, B.; Yu, B.; Karim, M.; Hu, H.; Sun, Y.; McGreevy, P.; Petocz, P.; Held, S.; Brand-Miller, J. Dietary sialic acid supplementation improves learning and memory in piglets. Am. J. Clin. Nutr. 2007, 85, 561-569. [CrossRef] [PubMed]

93. Morgan, B.L.; Oppenheimer, J.; Winick, M. Effects of essential fatty acid deficiency during late gestation on brain $\mathrm{N}$-acetylneuraminic acid metabolism and behaviour in the progeny. Br. J. Nutr. 1981, 46, 223-230. [CrossRef] [PubMed]

94. Georgi, G.; Bartke, N.; Wiens, F.; Stahl, B. Functional glycans and glycoconjugates in human milk. Am. J. Clin. Nutr. 2013, 98, 578S-585S. [CrossRef] [PubMed]

95. Jacobi, S.K.; Yatsunenko, T.; Li, D.; Dasgupta, S.; Yu, R.K.; Berg, B.M.; Chichlowski, M.; Odle, J. Dietary isomers of sialyllactose increase ganglioside sialic acid and concentrations in corpus callous and cerebellum and modulate the colonic microbiota of formula-fed piglets. J. Nutr. 2016, 146, 200-208. [CrossRef] [PubMed]

96. Sakai, F.; Ikeuchi, F.; Urashima, T.; Fujiwara, M.; Ohtsuki, K.; Yanahira, S. Effects of feeding sialyllactose and galactosylated $\mathrm{N}$-acetylneuraminic acid on swimming learning ability and brain lipid composition in adult rats. J. Appl. Glycosci. 2006, 63, 249-254. [CrossRef]

97. Oliveros, E.; Vazquez, E.; Barranco, A.; Ramirez, M.; Gruart, A.; Delgado-Garcia, J.M.; Buck, R.; Rueda, R.; Martin, M.J. Sialic acid and sialylated oligosaccharide supplementation during lactation improves learning and memory in rats. Nutrients 2018, 10, 1519. [CrossRef] [PubMed]

98. Bode, L. Human milk oligosaccharides at the interface of maternal-infant health. Breastfeed. Med. 2018, 13, S7-S8. [CrossRef]

99. Duska-McEwen, G.; Senft, A.P.; Ruetschilling, T.L.; Barrett, E.G.; Buck, R.H. Oligosaccharides enhance innate immunity to respiratory syncytial virus and influenza in vitro. Food Nutr. Sci. 2014, 5, 1387-1398.

100. Lis-Kuberka, J.; Orczyk-Pawiłowicz, M. Znaczenie fukozylowanych glikokoniugatów mleka ludzkiego w żywieniu noworodków i niemowląt. Postępy Hig. Med. Dośw. 2015, 69, 811-829. [CrossRef]

101. Newburg, D.S. Neonatal protection by an innate immune system of human milk consisting of oligosaccharides and glycans. J. Anim. Sci. 2009, 87, 26-34. [CrossRef]

102. Korhonen, T.K.; Väisänen-Rhen, V.; Rhen, M.; Pere, A.; Parkkinen, J.; Finne, J. Escherichia coli fimbriae recognizing sialyl galactosides. J. Bacteriol. 1984, 159, 762-766. [PubMed]

103. Matrosovich, M.N.; Gambaryan, A.S.; Tuzikov, A.B. Probing of the receptor-binding sites of the H1 and H3 influenza A and influenza B virus hemagglutinins by synthetic and natural sialosides. Virology 1993, 196, 111-121. [CrossRef] [PubMed]

104. Firon, N.; Ofek, I.; Sharon, N. Carbohydrate specificity of the surface lectins of Escherichia coli, Klebsiella pneumoniae, and Salmonella typhimurium. Carbohydr. Res. 1983, 120, 235-249. [CrossRef]

105. Mysore, J.V.; Wigginton, T.; Simon, P.M.; Zopf, D.; Heman-Ackah, L.M.; Dubois, A. Treatment of Helicobacter pylori infection in rhesus monkeys using a novel antiadhesion compound. Gastroenterology 1999, 117, 1316-1325. [CrossRef]

106. Lin, A.E.; Autran, C.A.; Espanola, S.D.; Bode, L.; Nizet, V. Human milk oligosaccharides protect bladder epithelial cells against uropathogenic Escherichia coli invasion and cytotoxicity. J. Infect. Dis. 2014, 209, 389-398. [CrossRef] [PubMed]

107. Martin-Sosa, S.; Martin, M.J.; Hueso, P. The sialylated fraction of milk oligosaccharides is partially responsible for binding to enterotoxigenic and uropathogenic Escherichia coli human strains. J. Nutr. 2002, 132, 3067-3072. [CrossRef] [PubMed] 
108. Schroten, H.; Stapper, C.; Plogmann, R.; Köhler, H.; Hacker, J.; Hanisch, F.G. Fab-independent antiadhesion effects of secretory immunoglobulin A on S-fimbriated Escherichia coli are mediated by sialyloligosaccharides. Infect. Immun. 1998, 66, 3971-3973.

109. Hirmo, S.; Kelm, S.; Iwersen, M.; Hotta, K.; Goso, Y.; Ishihara, K.; Suguri, T.; Morita, M.; Wadström, T.; Schauer, R. Inhibition of Helicobacter pylori sialic acid-specific haemagglutination by human gastrointestinal mucins and milk glycoproteins. FEMS Immunol. Med. Microbiol. 1998, 20, 275-281. [CrossRef]

110. Vacca-Smith, A.M.; Van Wuyckhuyse, B.C.; Tabak, L.A.; Bowen, W.H. The effect of milk and casein proteins on the adherence of Streptococcus mutans to saliva-coated hydroxyapatite. Arch. Oral Biol. 1994, 39, 1063-1069. [CrossRef]

111. Yolken, R.H.; Peterson, J.A.; Vonderfecht, S.L.; Fouts, E.T.; Midthun, K.; Newburg, D.S. Human milk mucin inhibits rotavirus replication and prevents experimental gastroenteritis. J. Clin. Investig. 1992, 90, 1984-1991. [CrossRef]

112. Idota, T.; Kawakami, H. Inhibitory effects of milk gangliosides on the adhesion of Escherichia coli to human intestinal carcinoma cells. Biosci. Biotechnol. Biochem. 1995, 59, 69-72. [CrossRef] [PubMed]

113. Newburg, D.S. Human milk glycoconjugates that inhibit pathogens. Curr. Med. Chem. 1999, 6, $117-127$. [PubMed]

114. Wada, A.; Hasegawa, M.; Wong, P.F.; Shirai, E.; Shirai, N.; Tan, L.J.; Llanes, R.; Hojo, H.; Yamasaki, E.; Ichinose, A.; et al. Direct binding of gangliosides to Helicobacter pylori vacuolating cytotoxin (VacA) neutralizes its toxin activity. Glycobiology 2010, 20, 668-678. [CrossRef] [PubMed]

115. Portelli, J.; Gordon, A.; May, J.T. Effect of compounds with antibacterial activities in human milk on respiratory syncytial virus and cytomegalovirus in vitro. J. Med. Microbiol. 1998, 47, 1015-1018. [CrossRef] [PubMed]

116. Salcedo, J.; Barbera, R.; Matencio, E.; Alegría, A.; Lagarda, M.J. Gangliosides and sialic acid effects upon newborn pathogenic bacteria adhesion: An in vitro study. Food Chem. 2013, 136, 726-734. [CrossRef] [PubMed]

117. Yang, B.; Chuang, H.; Yang, K.D. Sialylated glycans as receptor and inhibitor of enterovirus 71 infection to DLD-1 intestinal cells. Virol. J. 2009, 6, 141. [CrossRef] [PubMed]

118. Fuhrer, A.; Sprenger, N.; Kurakevich, E.; Borsig, L.; Chassard, C.; Hennet, T. Milk sialyllactose influences colitis in mice through selective intestinal bacterial colonization. J. Exp. Med. 2010, 207, 2843-2854. [CrossRef]

119. Naarding, M.A.; Dirac, A.M.; Ludwig, I.S.; Speijer, D.; Lindquist, S.; Vestman, E.L.; Stax, M.J.; Geijtenbeek, T.B.; Pollakis, G.; Hernell, O.; et al. Bile salt-stimulated lipase from human milk binds DC-SIGN and inhibits human immunodeficiency virus type 1 transfer to CD4+ T cells. Antimicrob. Agents Chemother. 2006, 50, 3367-3374. [CrossRef]

120. Ruvoën-Clouet, N.; Mas, E.; Marionneau, S.; Guillon, P.; Lombardo, D.; Le Pendu, J. Bile-salt-stimulated lipase and mucins from milk of 'secretor' mothers inhibit the binding of Norwalk virus capsids to their carbohydrate ligands. Biochem. J. 2006, 393, 627-634. [CrossRef]

121. Ackerman, D.L.; Doster, R.S.; Weltkamp, J.H.; Anoff, D.M.; Gaddy, J.A.; Townsend, S.D. Human milk oligosaccharides exhibit antimicrobial and anti-biofilm properties against group B Streptococcus. ACS Infect. Dis. 2017, 3, 595-605. [CrossRef]

122. Ackerman, D.L.; Carft, K.M.; Doster, R.S.; Welkamp, J.H.; Aronoff, D.M.; Gaddy, J.A.; Townsend, S.D. Antimicrobial and antibiofilm activity of human milk oligosaccharides against Streptococcus agalactoae, Staphylococcus aureus, and Acinetobacter baumanni. ACS Infect. Dis. 2018, 4, 315-324. [CrossRef] [PubMed]

123. Craft, K.M.; Thomas, H.C.; Townsend, S.D. Interrogation of human milk oligosaccharide fucosylation patterns for antimicrobial and antibiofilm trends in group B Streptococcus. ACS Infect. Dis. 2018, 4, 1755-1765. [CrossRef] [PubMed]

124. Lin, A.; Autran, C.A.; Szyszka, A.; Tscajadillo, T.; Huang, M.; Gudula, K.; Pridden, A.R.; Boons, G.J.; Lewis, A.L.; Donovan, K.S.; et al. Human milk oligosaccharides inhibits growth of group B Streptococcus. J. Biol. Chem. 2017, 292, 11243-11249. [CrossRef] [PubMed]

125. Craft, K.M.; Thomas, H.C.; Townsend, S.D. Sialylated variants of lacto-N-tetraose exhibit antimicrobial activity against Group B Streptococcus. Org. Biomol. Chem. 2018. [CrossRef] [PubMed]

126. Craft, K.M.; Gaddy, J.A.; Townsend, S.D. Human milk oligosaccharides (HMOs) sensitize group B Streptococcus to clindamycin, erythromycin, gentamicin, and minocycline on a strain specific basis. ACS Chem. Biol. 2018, 13, 2020-2026. [CrossRef] [PubMed] 
127. Comstock, S.S.; Li, M.; Wang, M.; Monaco, M.H.; Kuhlenschmidt, T.B.; Donovan, S.M. Dietary human milk oligosaccharides but not prebiotic oligosaccharides increase circulating natural killer cell and mesenteric lymph node memory $\mathrm{T}$ cell populations in noninfected and rotaviruss-infected neonatal piglets. J. Nutr. 2017, 147, 1041-1047. [CrossRef] [PubMed]

128. Laucirica, D.R.; Triantis, V.; Schoemaker, R.; Estes, M.K.; Ramani, S. Milk oligosaccharides inhibit human rotavirus infectivity in MA104 cells. J. Nutr. 2017, 147, 1709-1714. [CrossRef] [PubMed]

129. Mistry, N.; Inoue, H.; Jamshidi, F.; Storm, R.J.; Oberste, M.S.; Arnberg, N. Coxsackievirus A24 variant uses sialic acid-containing O-linked glycoconjugates as cellular receptors on human ocular cells. J. Virol. 2011, 85, 11283-11290. [CrossRef]

130. Yang, H.; Carney, P.J.; Chang, J.C.; Guo, Z.; Villanueva, J.M.; Stevens, J. Structure and receptor binding preferences of recombinant human A(H3N2) virus hemagglutinins. Virology 2015, 477, 18-31. [CrossRef]

131. Iwamori, M.; Takamizawa, K.; Momoeda, M.; Iwamori, Y.; Taketani, Y. Gangliosides in human, cow and goat milk, and their abilities as to neutralization of cholera toxin and botulinum type A neurotoxin. Glycoconj. J. 2008, 25, 675-683. [CrossRef]

132. Laegreid, A.; Kolstø Otnaess, A.B. Trace amounts of ganglioside GM1 in human milk inhibit enterotoxins from Vibrio cholerae and Escherichia coli. Life Sci. 1987, 40, 55-62. [CrossRef]

133. Otnaess, A.B.; Laegreid, A.; Ertresvag, K. Inhibition of enterotoxin from Escherichia coli and Vibrio cholerae by gangliosides from human milk. Infect. Immun. 1983, 40, 563-569. [PubMed]

134. Angeloni, S.; Ridet, J.L.; Kusy, N.; Gao, H.; Crevoisier, F.; Guinchard, S.; Kochhar, S.; Sigrist, H.; Sprenger, N. Glycoprofiling with micro-arrays of glycoconjugates and lectins. Glycobiology 2005, 15, 31-41. [CrossRef] [PubMed]

135. Straubinger, K.; Ninonuevo, M.; Bode, L. Human milk oligosaccharides alter the intestinal epithelial cell surface glycome: A proof-of-principle. FASEB J. 2010, 24. [CrossRef]

136. Jantscher-Krenn, E.; Zherebtsov, M.; Nissan, C.; Goth, K.; Guner, Y.S.; Naidu, N.; Choudhury, B.; Grishin, A.V.; Ford, H.R.; Bode, L. The human milk oligosaccharide disialyllacto-N-tetraose prevents necrotising enterocolitis in neonatal rats. Gut 2012, 61, 1417-1425. [CrossRef] [PubMed]

137. Comstock, S.S.; Wang, M.; Hester, S.N.; Li, M.; Donovan, S.M. Select human milk oligosaccharides directly modulate peripheral blood mononuclear cells isolated from 10-d-old pigs. Br. J. Nutr. 2014, 111, 819-828. [CrossRef] [PubMed]

138. Bode, L.; Kunz, C.; Muhly-Reinholz, M.; Mayer, K.; Seeger, W.; Rudloff, S. Inhibition of monocyte, lymphocyte, and neutrophil adhesion to endothelial cells by human milk oligosaccharides. Thromb. Haemost. 2004, 92, 1402-1410. [CrossRef] [PubMed]

139. Obermeier, S.; Rudloff, S.; Pohlentz, G.; Lentze, M.J.; Kunz, C. Secretion of 13C-labelled oligosaccharides into human milk and infant's urine after an oral (13C)galactose load. Isotopes Environ. Health Stud. 1999, 35, 119-125. [CrossRef]

140. Rudloff, S.; Pohlentz, G.; Diekmann, L.; Egge, H.; Kunz, C. Urinary excretion of lactose and oligosaccharides in preterm infants fed human milk or infant formula. Acta Paediatr. 1996, 85, 598-603. [CrossRef] [PubMed]

141. Rudloff, S.; Stefan, C.; Pohlentz, G.; Kunz, C. Detection of ligands for selectins in the oligosaccharide fraction of human milk. Eur. J. Nutr. 2002, 41, 85-92. [CrossRef] [PubMed]

142. Hill, D.R.; Newburg, D.S. Clinical applications of bioactive milk components. Nutr. Rev. 2015, 73, 463-476. [CrossRef] [PubMed]

143. Clark, R.H.; Gordon, P.; Walker, W.M.; Laughon, M.; Smith, P.B.; Spitzer, A.R. Characteristics of patients who die of necrotizing enterocolitis. J. Perinatol. 2012, 32, 199-204. [CrossRef] [PubMed]

144. Patel, A.L.; Kim, J.H. Human milk and necrotizing enterocolitis. Semin. Pediatr. Surg. 2018, $27,34-38$. [CrossRef] [PubMed]

145. Autran, C.A.; Schoterman, M.H.; Jantscher-Krenn, E.; Kamerling, J.P.; Bode, L. Sialylated galacto-oligosaccharides and 2 '-fucosyllactose reduce necrotising enterocolitis in neonatal rats. Br. J. Nutr. 2016, 116, 294-299. [CrossRef] [PubMed]

146. Autran, C.A.; Kellman, B.P.; Kim, J.H.; Asztalos, E.; Blood, A.B.; Spence, E.C.H.; Patel, A.L.; Hou, J.; Lewis, N.E.; Bode, L. Human milk oligosaccharide composition predicts risk of necrotising enterocolitis in preterm infants. Gut 2018, 67, 1064-1070. [CrossRef] [PubMed] 
147. Rasmussen, S.O.; Martin, L.; Østergaard, M.V.; Rudloff, S.; Roggenbuck, M.; Nguyen, D.N.; Sangild, P.T.; Bering, S.B. Human milk oligosaccharide effects on intestinal function and inflammation after preterm birth in pigs. J. Nutr. Biochem. 2017, 40, 141-154. [CrossRef]

148. Kurakevich, E.; Hennet, T.; Hausmann, M.; Rogler, G.; Borsig, L. Milk oligosaccharide sialyl $(\alpha 2,3)$ lactose activated intestinel CD11C cells through TLR4. Proc. Natl. Acad. Sci. USA 2013, 110, 17444-17449. [CrossRef]

149. Lane, J.A.; O'Callaghan, J.; Carrington, S.T.; Hickey, R.M. Transcriptional response of HT-29 intestinal epithetial cells to human and bovine milk oligosaccharides. Br. J. Nutr. 2013, 110, 2127-2137. [CrossRef]

150. Castillo-Courtade, L.; Han, S.; Lee, S.; Mian, F.M.; Buck, R.; Forsythe, P. Attenuation of food allergy symptoms following treatment with human milk oligosaccharides in a mouse model. Allergy 2015, 70, 1091-1102. [CrossRef]

151. de Moura Bell, J.M.L.N.; Cohen, J.L.; de Aquino, L.F.M.C.; Lee, H.; de Melo Silva, V.L.; Liu, Y.; Domizio, P.; Barile, D. An integrated bioprocess to recover bovine milk oligosaccharides from colostrum whey permeate. J. Food Eng. 2018, 216, 27-35. [CrossRef]

152. Martín-Sosa, S.; Martín, M.J.; García-Pardo, L.A.; Hueso, P. Sialyloligosaccharides in human and bovine milk and in infant formulas: Variations with the progression of lactation. J. Dairy Sci. 2003, 86, 52-59. [CrossRef]

153. Varki, A. Colloquium paper: Uniquely human evolution of sialic acid genetics and biology. Proc. Natl. Acad. Sci. USA 2010, 2, 8939-8946. [CrossRef] [PubMed]

154. Alisson-Silva, F.; Kawanishi, K.; Varki, A. Human risk of diseases associated with red meat intake: Analysis of current theories and proposed role for metabolic incorporation of a non-human sialic acid. Mol. Asp. Med. 2016, 51, 16-30. [CrossRef] [PubMed]

155. Bardor, M.; Nguyen, D.H.; Diaz, S.; Varki, A. Mechanism of uptake and incorporation of the non-human sialic acid N-glycolylneuraminic acid into human cells. J. Biol. Chem. 2005, 280, 4228-4237. [CrossRef] [PubMed]

156. Pham, T.; Gregg, C.J.; Karp, F.; Chow, R.; Padler-Karavani, V.; Cao, H.; Chen, X.; Witztum, J.L.; Varki, N.M.; Varki, A. Evidence for a novel human-specific xeno-auto-antibody response against vascular endothelium. Blood 2009, 114, 5225-5235. [CrossRef]

157. Takimori, S.; Shimooka, H.; Furukawa, J.; Yamashita, T.; Amono, M.; Fujitani, N.; Takegawa, Y.; Hammarstrom, L.; Kacskovics, I.; Shinohara, Y.; et al. Alteration of the N-glycome of bovine milk glycoproteins during early lactation. FEBS J. 2011, 278, 3769-3781. [CrossRef] [PubMed]

158. Hurum, D.C.; Rohrer, J.S. Determination of sialic acids in infant formula by chromatographic methods: A comparison of high-performance anion-exchange chromatography with pulsed amperometric detection and ultra-high-performance liquid chromatography methods. J. Dairy Sci. 2012, 95, 1152-1161. [CrossRef]

159. Tangvoranuntakul, P.; Gagneux, P.; Diaz, S.; Bardor, M.; Varki, N.; Varki, A.; Muchmore, E. Human uptake and incorporation of an immunogenic nonhuman dietary sialic acid. Proc. Natl. Acad. Sci. USA 2003, 100, 12045-12050. [CrossRef]

160. Abrams, S.A.; Landers, S.; Noble, L.M.; Poindexter, B.B.; Daniels, S.; Corkins, M.; de Ferranti, S.; Golden, N.H.; Kim, J.H.; Magge, S.N.; et al. Donor human milk for the high-risk infant: Preparation, safety, and usage options in the United States. Pediatrics 2017, 139, e20163440. [CrossRef]

161. Li, Y.; Nguyen, D.N.; de Waard, M.; Christensen, L.; Zhou, P.; Jiang, P.; Sun, J.; Bojesen, A.M.; Lauridsen, C.; Lykkesfeldt, J.; et al. Pasteurization procedures for donor human milk affect body growth, intestinal structure, and resistance against bacterial infections in preterm pigs. J. Nutr. 2017, 147, 1121-1130. [CrossRef]

162. Meredith-Dennis, L.; Xu, G.; Goonatilleke, E.; Lebrilla, C.B.; Underwood, M.A.; Smilowitz, J.T. Composition and variation of macronutrients, immune proteins, and human milk oligosaccharides in human milk from nonprofit and commercial milk banks. J. Hum. Lact. 2018, 34, 120-129. [CrossRef] [PubMed]

163. Wesolowska, A.; Sinkiewicz-Darol, E.; Barbarska, O.; Strom, K.; Rutkowska, M.; Karzel, K.; Rosiak, E.; Oledzka, G.; Orczyk-Pawiłowicz, M.; Rzoska, S.; et al. New Achievements in High-Pressure Processing to Preserve Human Milk Bioactivity. Front. Pediatr. 2018, 6, 323. [CrossRef] [PubMed]

164. Daniels, B.; Coutsoudis, A.; Autran, C.; Amundson Mansen, K.; Israel-Ballard, K.; Bode, L. The effect of simulated flash heating pasteurisation and Holder pasteurisation on human milk oligosaccharides. Paediatr. Int. Child Health 2017, 37, 204-209. [CrossRef] [PubMed] 
165. Grabarics, M.; Csernák, O.; Balogh, R.; Béni, S. Analytical characterization of human milk oligosaccharides-Potential applications in pharmaceutical analysis. J. Pharm. Biomed. Anal. 2017, 146, 168-178. [CrossRef] [PubMed]

166. Bakker-Zierikzee, A.M.; Alles, M.S.; Knol, J.; Kok, F.J.; Tolboom, J.J.; Bindels, J.G. Effects of infant formula containing a mixture of galacto- and fructo-oligosaccharides or viable Bifidobacterium animalis on the intestinal microflora during the first 4 months of life. Br. J. Nutr. 2005, 94, 783-790. [CrossRef] [PubMed]

167. Moro, G.; Arslanoglu, S.; Stahl, B.; Jelinek, J.; Wahn, U.; Boehm, G. A mixture of prebiotic oligosaccharides reduces the incidence of atopic dermatitis during the first six months of age. Arch. Dis. Child. 2006, 91, 814-819. [CrossRef] [PubMed]

168. Arslanoglu, S.; Moro, G.E.; Schmitt, J.; Tandoi, L.; Rizzardi, S.; Boehm, G. Early dietary intervention with a mixture of prebiotic oligosaccharides reduces the incidence of allergic manifestations and infections during the first two years of life. J. Nutr. 2008, 138, 1091-1095. [CrossRef] [PubMed]

169. Vandenplas, Y.; De Greef, E.; Veereman, G. Prebiotics in infant formula. Gut Microbes 2014, 5, 681-687. [CrossRef]

170. Weichert, S.; Jennewein, S.; Hüfner, E.; Weiss, C.; Borkowski, J.; Putze, J.; Schroten, H. Bioengineered 2'-fucosyllactose and 3-fucosyllactose inhibit the adhesion of Pseudomonas aeruginosa and enteric pathogens to human intestinal and respiratory cell lines. Nutr. Res. 2013, 33, 831-838. [CrossRef]

171. Meli, F.; Puccio, G.; Cajozzo, C.; Ricottone, G.L.; Pecquet, S.; Sprenger, N.; Steenhout, P. Growth and safety evaluation of infant formulae containing oligosaccharides derived from bovine milk: A randomized, double-blind, noninferiority trial. BMC Pediatr. 2014, 14, 306. [CrossRef]

172. Guo, L.; Chen, X.; Xu, L.; Xiao, M.; Lu, L. Enzymatic synthesis of 6'-sialyllactose, a dominant sialylated human milk oligosaccharide, by a novel exo- $\alpha$-sialidase from Bacteroides fragilis NCTC9343. Appl. Environ. Microbiol. 2018, 84, e00071-18. [CrossRef] [PubMed]

173. Albrecht, S.; Lane, J.A.; Mariño, K.A.; Busadah, K.A.; Carrington, S.D.; Hickey, R.M.; Rudd, P.M. A comparative study of free oligosaccharides in the milk of domestic animals. Br. J. Nutr. 2014, 111, 1313-1328. [CrossRef] [PubMed] 